\title{
Beyond Form and Fancy: The Merchant Palaces of Kazimierz Dolny in Poland
}

\author{
by KATIE JAKOBIEC
}

In 1976 the Polish art historian Jan Białostocki published The Art of the Renaissance in Eastern Europe, which has since proven to be a sound springboard for revisionist studies of the Renaissance. ${ }^{1}$ In this ambitious book, he defined the word Renaissance as a style that was formulated in Italy and spread to various parts of Europe, including the PolishLithuanian Commonwealth, Bohemia and Hungary, where it arrived as a 'royal fancy'. ${ }^{2}$ He described how Italian artists working north of the Alps implemented an all'antica language of 'forms' to produce a 'transplanted Italian Renaissance, sometimes of high artistic distinction'. ${ }^{3}$ These 'forms', together with associated techniques and ideas, were eventually taken over by local builders and sculptors and were utilised either with little modification or by adapting them to artistic traditions and needs of particular cultural areas, in ways that were quite distinct from the intentions of the Italian inventors. ${ }^{4}$ Having traced this development of style, Białostocki concluded his book with the buildings that form the focus of this present study - the palaces of merchant brothers Nicolaus and Christopher Przybyło completed in 1615 by an unidentified builder in Kazimierz Dolny, a port city on Poland's Vistula River (Fig. 1). For Białostocki, these buildings represented the finale of the process of the adaptation of the Renaissance that had now become completely popularised and had thus 'run its full course'. ${ }^{5}$ In contrast to the much earlier Sigismund Chapel (1517-33), the royal mausoleum in Kraków designed by the Italian Bartolommeo Berrecci, which was celebrated by Białostocki for its 'original' and 'pure form', the Przybyło palaces in Kazimierz Dolny did not embody such an ideal or, for that matter, adopt any coherent symbolism. ${ }^{6}$ Instead, they exemplified the reinterpretation and imagination of local, 'simple-minded artisans'. Profusely ornamented with relief sculpture, Białostocki described them as being made as if 'of pastry by a naïve hand' with reliefs that 'do not show any intermediary planes, nor any subtlety of stratification in depth', adding that the primary concern was tactility. ${ }^{7}$

This article examines the sculptural façades of these two adjoining palaces which are located on Kazimierz Dolny's market square. My focus is on the architectural impasto, formed from the thick application of stucco, which Białostocki compared to pastry dough because, for him, it rather recalled a malleable mass that was worked by hand, a material appearing to be slapped onto the surface, and then kneaded, stretched and folded (Fig. 2). This architectural exploitation of stucco, however, has never been 


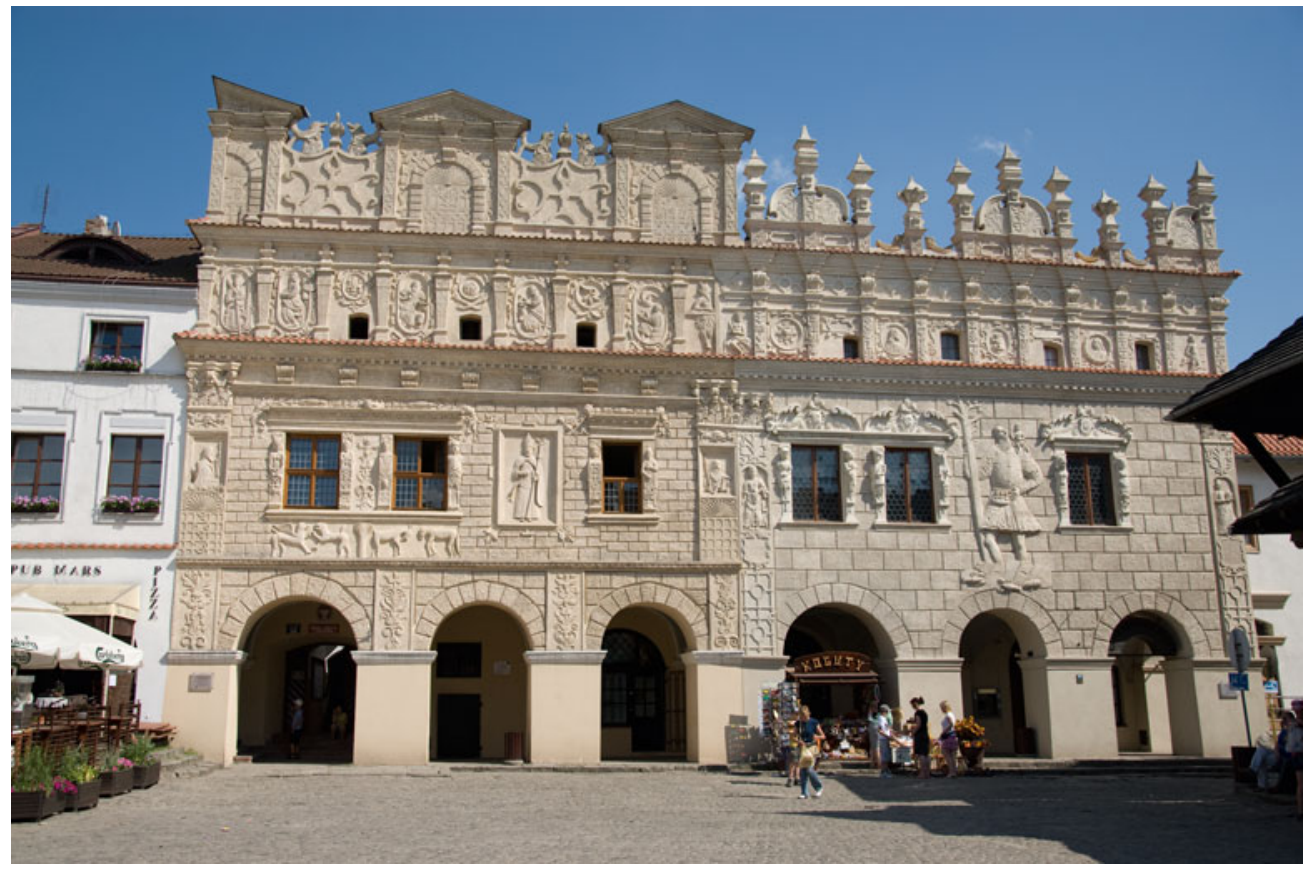

Fig. 1. Kazimierz Dolny, Palaces of Nicolaus and Christopher Przybyło, façades overlooking the city square

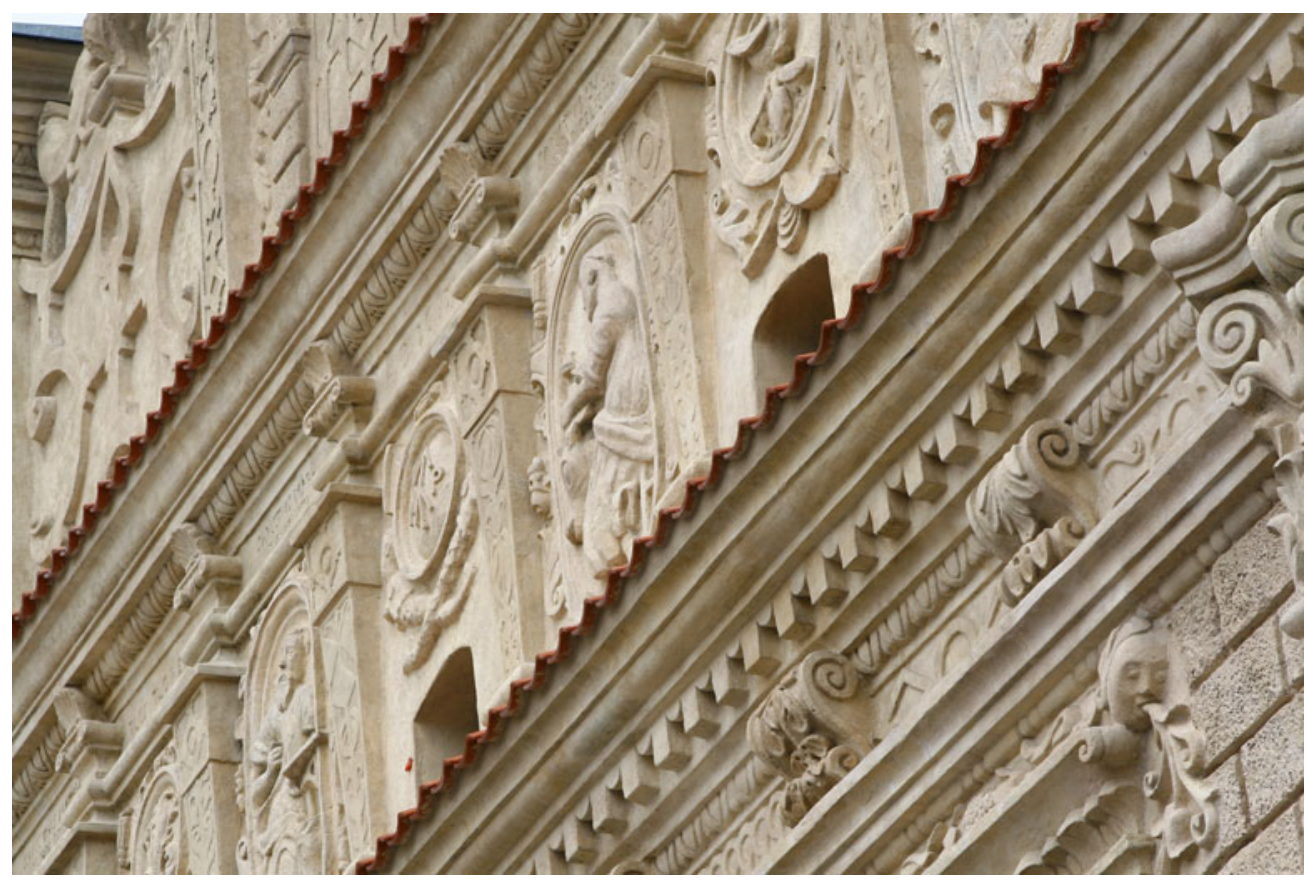

Fig. 2. Kazimierz Dolny, Palace of Nicolaus Przybyło, façade 
seriously considered. In its time, in both Poland and elsewhere, relief sculpture was a dynamic area of artistic production and stucco was a leading new technology used for copying and casting. ${ }^{8}$ It will be shown that Kazimierz Dolny - a mercantile centre and cultic site - took up and adapted this technique and paired it with a distinct iconography in order to engage in current cultural processes of imitation and reference making. As a result, the palaces of the Przybyło brothers were able to express a new civic identity that stamped its inclusivity in a broader spatial realm frequented by merchants and pilgrims. More broadly, this study contributes to the recent interest in the role of buildings shaping cultural systems.

\section{KAZIMIERZ DOLNY IN HISTORIOGRAPHY}

The architecture of Kazimierz Dolny has occupied a curious position in historiography. Evocative vocabulary has been used to describe its buildings, revolving on terms such as 'barbarian', 'late and low', 'folk', 'provincial', and even 'Gothic'. 9 Such terms also applied to the all-over ornament of the Przybyło palaces, which then elicited a whole range of more specific interpretations, such as manifesting the lingering medieval imagination, or providing an example of conspicuous consumption, or a display of a boisterous reluctance to conform to the canon. ${ }^{10}$ In short, these buildings have both attracted and repulsed their commentators, who were also divided in their responses in other ways: Polish scholars did not celebrate the tactile quality in the way that German historians prized its 'blindness' or its anti-optical tendencies which they considered as characteristics of German art. ${ }^{11}$ More recently, it has also been noted that the Przybyło palaces in Kazimierz Dolny are not, in fact, particularly vernacular (as Białostocki had implied) because the technique of stucco with relief modelling was not at all unique to this region but belonged very much to an international language of visual culture. ${ }^{12}$ Indeed, like many other buildings in Poland, they can be seen as trans-regional in nature, having both traditional characteristics and those deriving from fashions elsewhere. ${ }^{13}$ In other words, Polish cities, including smaller towns such as Kazimierz Dolny, were by no means excluded from the cultural trends and tastes sweeping Europe during this period. Thus the notion of imitation central to diffusionist models dwelling on artistic influence of the kind proposed by Białostocki is not as straight-forward and simple as once believed. In fact, a consideration of the plurality of the sources and associations of the stucco reliefsculptures in Kazimierz Dolny will show just how complex and multifaceted the façades were in their conception, and will draw attention to the inadequacy of the simplistic classification into vernacular or all'antica categories, or even some hybrid of the two. Curiously, however, Białostocki's comparison of the stuccowork to pastry dough provides insight into the historical realities of how buildings were produced and engaged with in Kazimierz Dolny, and it is through this analogy that, as we will be seeing, the stucco façades offer historians a dynamic and layered model of cultural interplay.

THE STRENGTH OF LOOSE TIES

The notion of association (or metaphor), regarding supposed preferences and prejudices, that is often perceptible in the historiography of architectural history, provides a useful 
way to think about how buildings were understood in their original contexts. Such impressions can be extremely deep and may not easily be untangled since they often derive from memory or emotional intelligence. For example, an instinct to touch or even taste might reveal ways in which our relationship to the built environment is shaped by multifarious experiences (physical or vicarious) with the material world more broadly. For Białostocki, his comment about dough may reveal something of his own tactile experience, as well as perhaps of his debt to the writings of Leonardo da Vinci and the views he expressed of the merits of painting over sculpture:

The sculptor in creating his work does so by the strength of his arm and the strokes of his hammer ... a most mechanical exercise often accompanied by much perspiration .... His face is smeared all over with marble powder so that he looks like a baker ... and his house is dirty and filled with flakes and dust of stone. ${ }^{14}$

Leonardo's evaluation was mainly focused on the manual labour required by sculptors who, like bakers, rolled up their sleeves and, by necessity, got dirty, as distinct from painters whose working processes were much more cerebral. Relief sculpture - 'the elevation or projection of a design, or parts of a design, from a plane surface' - could well have triggered memory of such a paragone debate given its place between painting and true sculpture 'in the round'; 15 or of further debates, in the sixteenth century, about the hierarchies of different media and techniques, and about valuable and inferior materials. ${ }^{16}$ In other arenas, the senses of touch and taste - inferior to that of sight - were often associated with carnal pleasures and connoted vulgarity and crudeness, ${ }^{17}$ and related to long established ideas about labour and artistic status and judgement. Thus, in Kazimierz Dolny, the combination of the stucco material and the relief-sculptural technique could well be regarded, especially by later writers, as discordant and troubling, and the merchant houses could stand for the provincial 'other', in being lacking in the values expected of higher strata of art and design. ${ }^{18}$

Architecture during the Early Modern period also engaged with critical debates over the notion of mimesis. Vitruvius had forcefully expressed a preference for architecture that fulfilled - and expressed - its structural purpose, and, in his discussion of fresco painting (which follows his chapters on stucco), he made clear his disdain for decoration that diverged from 'actual realities' and 'truthful representations of definite things', criticising in particular those who took pleasure in representations of monstrosities such as 'half-length figures, some with human heads, and others with the heads of animals'. ${ }^{19}$ He dwelled at even greater depth on instances of architectural 'defects', such as 'reeds are put in the place of columns' where it is impossible that they could really support a roof, exclaiming that 'such things do not exist and cannot exist and never have existed'. ${ }^{20}$ Vitruvius, moreover, severely censored those who find delight rather than fault in pictures of things that have no reason for being, ${ }^{21}$ in contrast to architecture that mirrored the workings of nature. The stucco-covered architecture at Kazimierz Dolny strays far from this Vitruvian ideal and from the principle of imitating nature but it cannot be said, as we will shortly be seeing, to be lacking in sophistication, or lacking in any erudite conception of imitation and reference making.

This non-canonical conception of architecture does only apply to Kazimierz Dolny's stucco fronted buildings. Also seen there is the sgraffito façade which - despite its 
initial popularity in the early modern period - has been similarly disregarded by later historians of architecture, as has recently been discussed by Alina Payne. This lack of engagement is again mainly on account of an ingrained preference for tectonic construction, and for the heavy and deeply modelled palace façades underpinned by the example of Antiquity. ${ }^{22}$ Thus the lacy and intricate detail of the sgraffito technique - 'a flamboyant, extreme instance of pure ornament' created by scratching and incising - challenges traditionalist ideas about architectural practice, and also about the influence of minor arts, $^{23}$ in that sgraffito had a range of sources with similar modes of production, such as textiles, ceramics, carpets, metalwork, and prints. ${ }^{24}$ The argument put forward by Payne is that the circulation of such objects during the Early Modern period would have fuelled a taste for all-over ornament, intricately worked surfaces, and new pattern and design ideas, which then extended to the architectural skin of palace façades, and the same kind of argument would seem to be applicable to the stucco façades in Kazimierz Dolny. Relief sculpture has commonalities with different kinds of artwork, such as coins, medals, plaquettes and prayer books, and these are often linked to manufacturing processes involving stamping and impressing, and thus replication. In other words, the concept of replication should be considered a common trait of all the objects here mentioned. Take for instance prayer books with soft white leather bindings, of the kind that were available in Kazimierz Dolny and also prevalent elsewhere in Poland: these were manufactured by being heated with metal brands and stamped with impressions depicting both vegetal and floral patterns as well as holy figures with inscriptions. ${ }^{25}$ While it is perhaps dangerous to make direct comparisons, the parallels between the white leather and the stuccowork of the façades, with their pronounced relief surfaces, as well as the similarities in the types of motifs and compositional designs that are employed are still compelling. This may suggest that it was the availability of appealing and much admired luxury objects such as white-leather books, and their intended repetitious service in prayer along with their ornamental and tactile qualities, that led to new approaches being taken up for palace façades.

Relief surfaces, however, were hardly novel, and they are associated with many kinds of objects suggesting a continuity with the medieval period and not just the impact of new tastes and new technologies. These more traditional objects included large-scale works such as jubés (choir screens), tombs, funerary monuments, and domestic furnishings such as ceramic stoves. Tombs and funerary monuments were especially prevalent in Poland, and include those belonging to the sandstone and marble interior of the already mentioned Sigismund Chapel, as well as Veit Stoss's bronze Epitaph of Filippo Buonaccorsi (1500-10), and numerous other bronze plaques by the Vischer workshop. Such sculptural reliefs would inevitably have carried religious connotations, and may have even aroused a tactile response, born from the handling, caressing of portable objects, or even wearing them on or around the body. Works in the secular sphere include the spectacular Great Stove (1545) of the Artus Court in Gdańsk, a grand hall intended as a meeting place for merchants, which depicts over five hundred tiles, by potter Georg Stelzener, showing portraits of European leaders and personifications of virtues in relief (Fig. 3 and Fig. 4). ${ }^{26}$ It would have conveyed its complex political, religious, and cultural meanings partly by drawing merchants to its warmth and, again, by presenting a tactile surface inviting to be touched. Smaller works would have included 


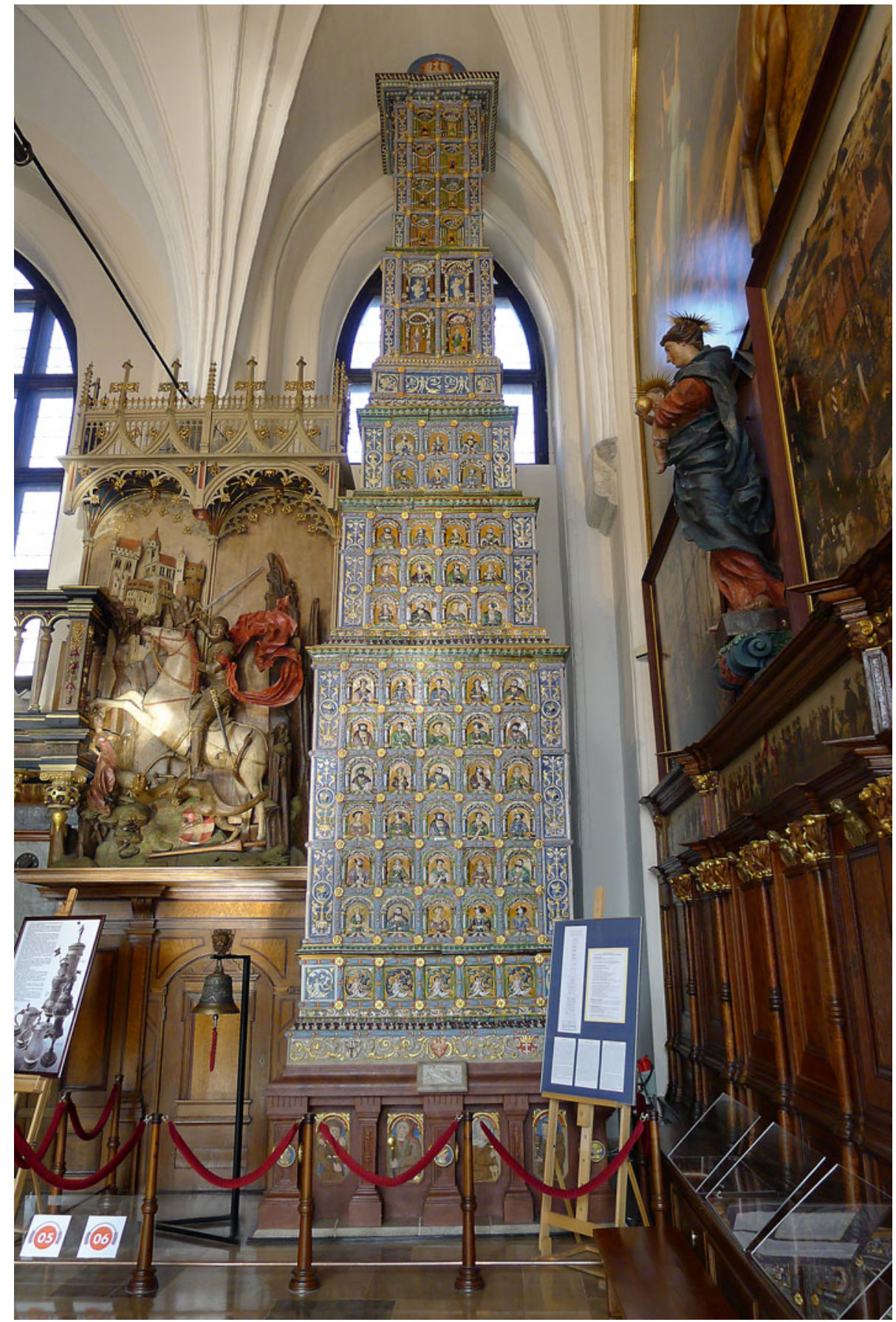

Fig. 3. Gdańsk, Artus Court, Great Stove 


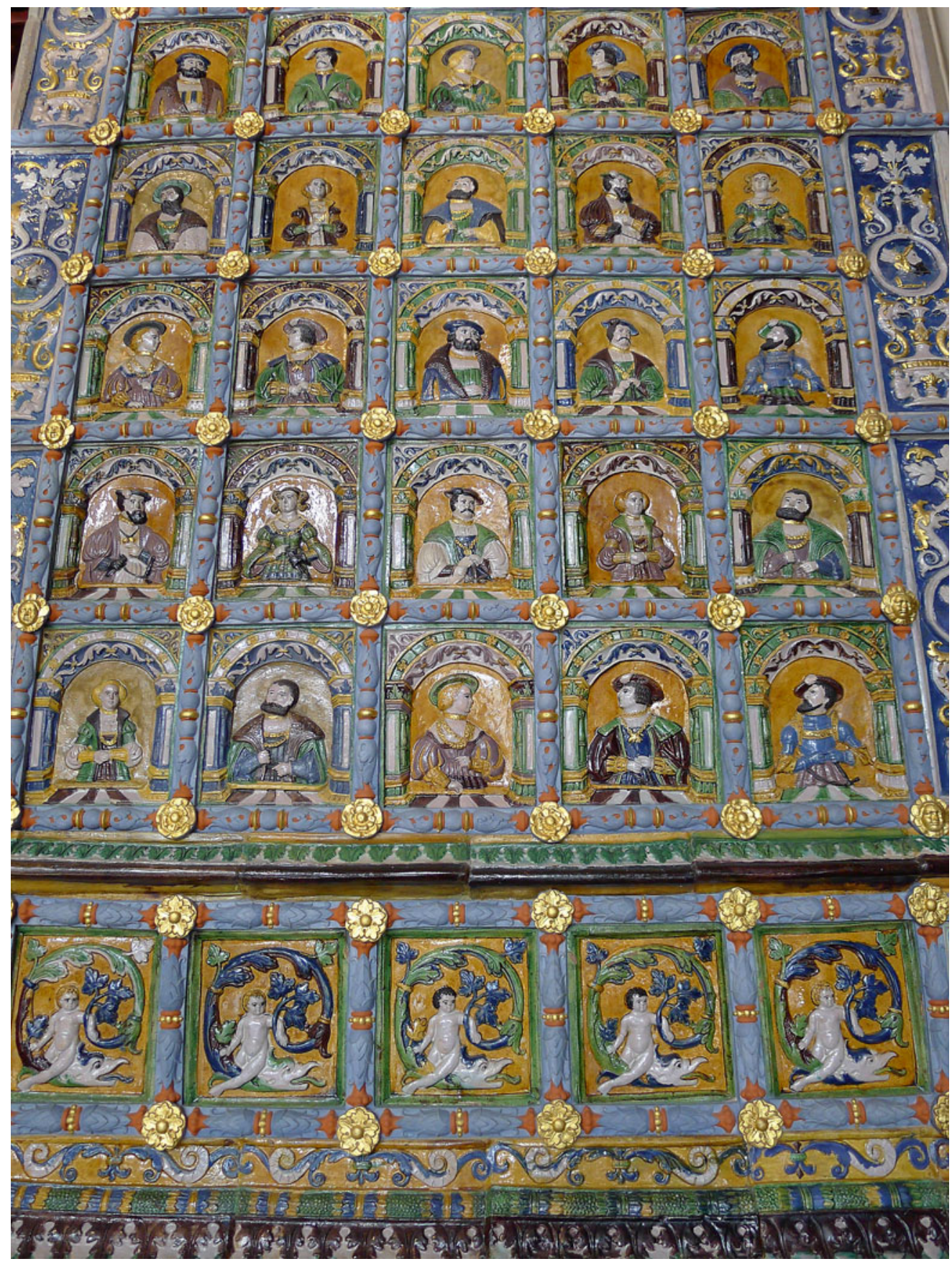

Fig. 4. Gdańsk, Artus Court, Great Stove, detail 
portable ceramic or metal cups or the fashionable metal belts worn especially in Early Modern Poland, together with other luxury objects such as furnishings and smallscale collectables obtained via trade networks, and also the more common mass-produced items such as books and dining ware of various qualities. The associations of the relief sculpture seen on the palaces in Kazimierz Dolny would thus have been informed by a wide range of material objects but especially those that would have often been touched, a plurality which does not easily lend itself to the linearity of time and space presented in traditional historiography of our discipline, but which makes very plausible the idea that buildings too rely on concepts of copying, and have a notional potential to be touched - or even tasted. ${ }^{27}$

\section{THE LIMESTONE HILLS OF KAZIMIERZ DOLNY}

Despite their outward appearance, however, the Przybyło palaces in Kazimierz are actually constructed from local limestone. The city is perfectly nestled between forested hills and the Vistula River. These not only define the city's topographic character but they also account for the city's economic success during the Early Modern period, and, not coincidently, the hills provided the constructional material used for the buildings, and the main ingredients too for their stucco. ${ }^{28}$ The second half of the sixteenth century had seen the city become a significant entrepôt of the Polish grain trade. ${ }^{29}$ Its strategic location on the Vistula River, the main artery of Early Modern Poland's trade, had seen local merchants engaging in the enterprise, which involved the storage of the commodity in the granaries located on the river banks before the grain's shipment to Gdańsk, from where it was exported to other ports in northern Europe. ${ }^{30}$ Between 1574 and 1630, based on the estimated numbers of grain units shipped, Kazimierz was at the peak of its activity. ${ }^{31}$ Simultaneously, the city was under wholesale reconstruction.

Limestone was the basic constructional material used for the city's grandest buildings, and it was far from common. The limestone hills were the private property of wealthy citizens, and restricted access meant that building in stone was a matter of privilege. According to the estimate of the Polish architectural historian, Adam Miłobedzki, ninety-four per cent of churches in Poland in the first quarter of the sixteenth century were wood constructions, ${ }^{32}$ with few of them, therefore, having been replaced by buildings made of stone. Limestone was thus a valuable commodity, which was sold locally in lasts (the same measuring unit as for grain), and was sold and shipped to cities such as Warsaw and Lublin. ${ }^{33}$ Owners of limestone hills sometimes sold access to their hills in the form of leases specifying the number of 'full kilns' to be excavated. A contract from 1710, for example, states that the lessee of the hills is to pay nine Polish złoty for every 'full kiln' of stone. ${ }^{34}$ The local 'white stone' was highly desirable but available in only limited supply and the locals were raising concerns regarding its depletion. As a siliceous limestone, it is highly porous with medium durability, but after several months of 'seasoning' its strength increases by more than sixty per cent. ${ }^{35}$ Its virtue is that it is relatively lightweight, easy to shape and impressively versatile. The city's stone-buildings were constructed from large, and differently shaped blocks of limestone, although for scrolled gables red 
brick was used for their supports (Fig. 5). In certain buildings, including the Przybyło palaces and the sgraffito-covered edifices, however, the surfaces of the walls were covered with stucco, giving them an imparted uniformity and in a way masking the uneven blocks assembled behind. ${ }^{36}$ Yet the stucco was still referencing stone through its imitation of it. For example, the sgraffito technique was used for the granaries to create an effect of impeccably-cut slabs of stone continuing to the edges of the buildings. The stucco employed for the Przybyło palaces, in addition, provided a display of craftsmanship and skill of a kind suited to cosmopolitan cities (Fig. 6). ${ }^{37}$

Stone in its multiple guises was an expression of durability, permanence, and magnificence. It resisted the elements, especially fire; and its firmness, weight, hardness and strength, as well as its associations with rarity, privilege, power and security, were all traits and associations that signified its worth. ${ }^{38}$ Merchant houses such as the Przybyło palaces were called in Polish kamienice (plural), a term that refers to their material kamien, or stone. ${ }^{39}$ In the sixteenth century, a kamienica (singular), or a 'stone house', referred to the building's intrinsic materiality, its stoniness, and using stone (or brick) rather than wood was a rare sight in the Early Modern Polish cityscape. In contracts pertaining to Kazimierz Dolny, stone became a crucial descriptor of buildings of high value and status; and, as I have argued elsewhere, legal documents and property sales of around 1600 show that the citizens of Kazimierz Dolny considered building materials as one of the chief indicators of their property's value. This was especially because it referenced the transition from an initial wooden construct to a stone edifice and, in addition, it was evidence of the owner's investment in the city. In his last will and testament, Nicolaus Przybyło specified that his properties were stone constructed 'by the labour of his own hands', which thus emphasised the importance of the constructional process, as well as his rights to the property's ownership. ${ }^{40}$ Sometimes the local merchants really got their hands dirty, supplying the limestone material to the construction site and in some cases physically breaking it up for use. ${ }^{41}$ Patrons, of course, were credited with the initiative to build, and this was sometimes specifically seen by the citizens of Kazimierz Dolny as bringing magnificence to the city. On his epitaph Nicolaus Przybyło was praised precisely for such an achievement: for bringing fame and status to the city and for hosting visiting dignitaries in a 'magnificent' way. This contribution to the city was reinforced by the fact that he created a worthy site for such hosting in constructing a palace with a façade that would interact with an urban space frequented by travellers, merchants and pilgrims. More generally, the city's stone fabric became fundamental to its identity, projecting a distinguished image that signalled the values of the merchants, especially that of trust in the unreliable world of trade. This image, however, could be enhanced further by the use of stucco to provide additional ornament and imagery.

\section{STUCCO}

The stucco medium used for sculpture and architectural decoration is hard to define with any great precision, and there was no single recipe for its production. ${ }^{42}$ Stucco had been originally popularised by the Romans who made it by burning marble or travertine, combining the lime obtained with pulverised marble and other ingredients. ${ }^{43}$ 
Fig. 5. Kazimierz Dolny, granary of Christopher Przybyło, gable with exposed limestone and red brick

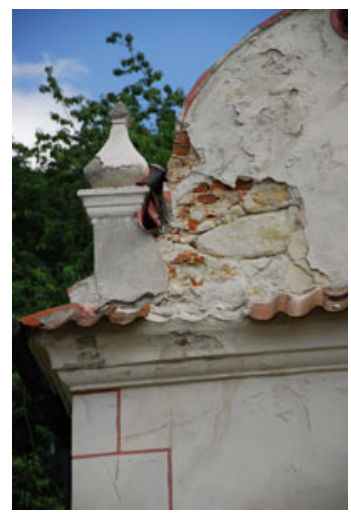

Vitruvius, giving credit to the Greeks for its invention, focused on the way stucco was made, specifying the correct ingredients for it to be applied to walls 'it will have strength and brilliancy, and an excellence that will last to a great age'. ${ }^{44} \mathrm{He}$ described it as a durable material which was applied in diverse ways, such as to wall decorations and vaults of tombs and palaces. ${ }^{45}$ Pliny the Elder was also interested in the recipes for stucco, distinguishing between different types of limestone and their qualities needed for building (walling) or plastering, which speaks about the differences in the raw material itself - whether it is hard or porous - in determining its suitability for different applications. ${ }^{46}$ In his Natural History, he also made reference to 'other ingredients', specifically those used for the temple of Minerva at Elis where milk and saffron were added into the recipe, so that 'if one wets one's thumb with saliva and rubs it on the plaster, the latter still gives off the smell and taste of saffron' ${ }^{47}$

Although often a substitute for carved marble, stucco was a medium with wideranging applications and physical qualities. Leon Battista Alberti remarked that to make lime ancient architects had preferred a 'white', extremely hard and compact stone, as it was suitable for many types of work. Another desirable type of stone was porous, this being best for plastering because it was easier to work with and created a splendid finish. He noted that, in the coastal region of Edui in France, lime was 'made from shells of oysters and mussels, for want of any stone'. He also mentions gypsum as another 'type of lime' that required the stone to be roasted for 'no more than twenty hours, whereas that for lime needs at least sixty'. He identified four types of gypsum in Italy, two translucent and two opaque. The opaque types, resembled dense chalk, whitish and very pale, that made the 'more lustrous stucco for cornices and figurines'. A type of gypsum found near Rimini gave 'the impression of being marble or alabaster' which Alberti had 'sawn into slabs that make excellent facing'; and he also discussed the process of making lime. ${ }^{48}$

In general, the mixture was given body by the addition of sand or marble dust, and applied to the surface with an iron trowel and spread with a float in layers. In contrast to carving - the cutting away of stone - it was applied in layers, and it required particularised skills of craft and manufacture. Unlike marble, moreover, stucco was tool- or 


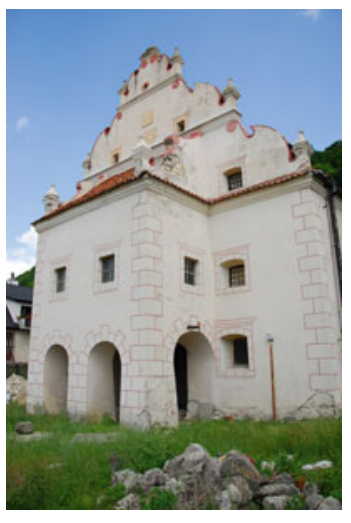

Fig. 6. Kazimierz Dolny, granary of Christopher Przybyło, façade

hand- modelled, and sometimes, when it was appropriate and possible, with the assistance of moulds. ${ }^{49}$ To execute a relief, projecting areas would first be defined with courses of brick or, sometimes, attached armatures or supporting structures. ${ }^{50}$ Then, a preliminary sketch could be incised on the wall surface in order to guide the stuccatore (sztukator in Polish), who would proceed by completing the design using tools such as spatulas for shaping and indenting, knives and sharp instruments for cutting and incising, stamps for pressing and moulds, before finally modelling by hand and caressing the material substance into its final form.

The effects can sometimes be both surprising and also alluring, and it is the material form that garners curiosity as much as anything else. Rather as Adrian Stokes felt an urge to touch the surfaces of the marble reliefs in the Tempio Malatestiano in Rimini, ${ }^{51}$ the beholder is tempted to touch a stucco surface, in order to validate the nature of the material and its performance in deceiving the eye. For example, stucco might imitate marble and imitate load-bearing architectural elements such as ashlar masonry, projecting cornices, capitals and their elaborate vegetal capitals. This duality is especially evident on the façade of Nicolaus Przybyło's palace, where, for example, one pilaster falls noticeably about a couple of centimetres short of the cornice, the result being architectural but definitely not tectonic (Fig. 7). The stucco material was thus the most suitable for this kind of imitative but deceitful play.

Knowledge of ancient stuccowork had been enhanced by the sixteenth-century exploration of Nero's Domus Aurea in Rome, and the study of its low-relief decorations executed in lime plaster, which Giorgio Vasari in 1550 described as stucco and stucchi. ${ }^{52}$ Vasari credited Giovanni da Udine for the supposed rediscovery of the recipe for this stucco, $^{53}$ a material then used for important commissions in Rome including Pope Leo X's private loggia (the Logge) in the Vatican (1518-19) and Cardinal Giulio de' Medici's Villa Madama (1518), and, later, the Fontainebleau palace (1531 onwards) of King Francis I of France, who requested a 'young man able to work in painting and stucco' and imported large quantities of Italian marble to produce it'. ${ }^{54}$ In architecture, external plasterwork had been well established by the turn of the sixteenth century, and 


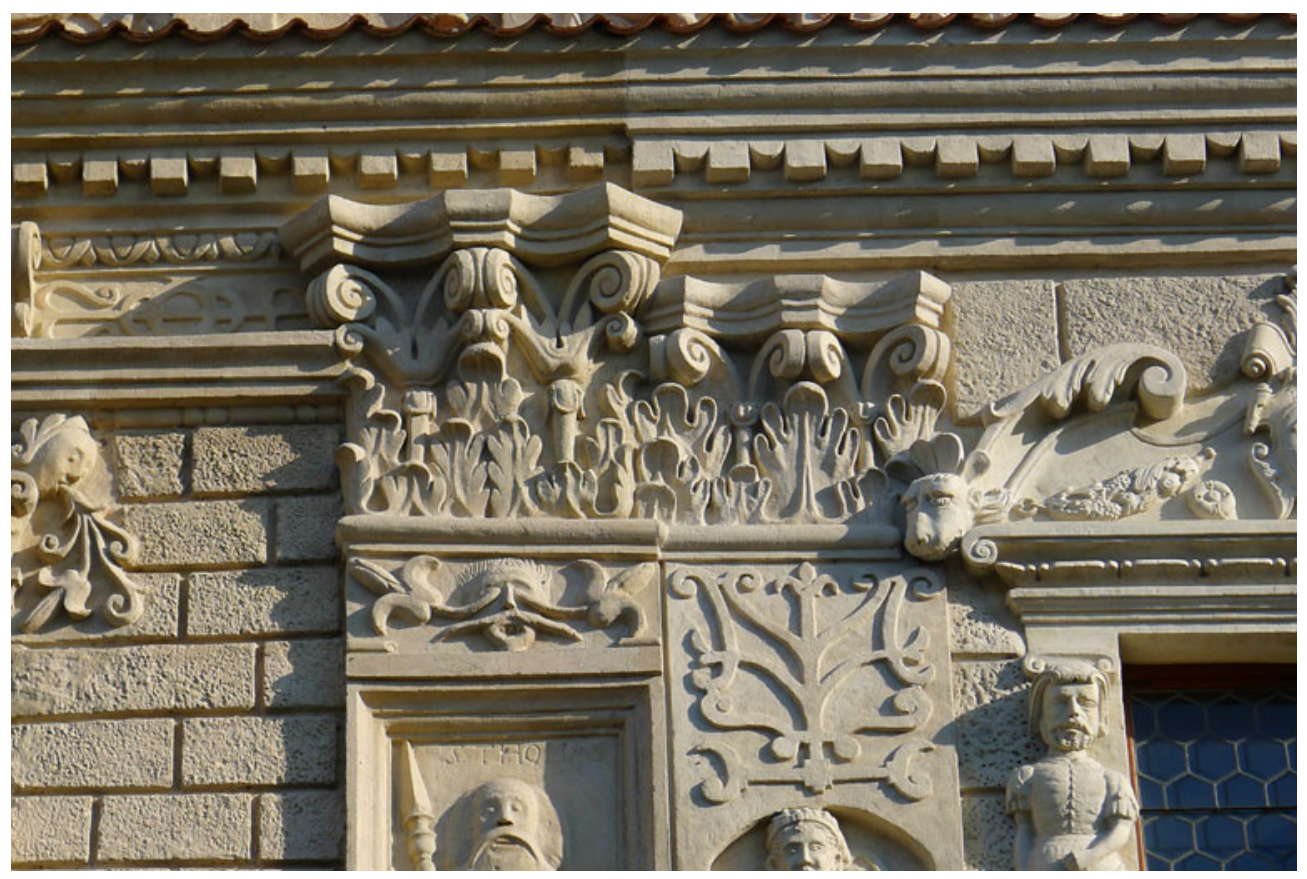

Fig. 7. Kazimierz Dolny, Palace of Christopher Przybyło, façade detail of pilaster

an exterior kind of stucco was pioneered by Bramante in his Palazzo Caprini (c. 1510; destroyed), 55 and was used for innumerable subsequent buildings such as Giulio Romano's Palazzo Te in Mantua (begun 1525). Stucco, thereafter, was understood as an Italian specialty, a 'gift' to Europe. ${ }^{56}$ Nevertheless, given its many different recipes, stucco is also regarded, rightly, as a 'local concoction embodying specific physical properties that result in a novel artistic quality'. ${ }^{57}$

In Poland, stucco was soon incorporated into an already diverse palette of material options. It was employed to remarkable effect by the Italian architect and sculptor Santi Gucci (c. 1530-1600) and by his workshop and followers in numerous chapels and palaces. For chapels, such as the impressive Firlej Chapel in the city of Bejsce (c. 1600), the medium was used to construct monumental architectural frameworks that were filled with figures of varying scale and in low or high relief, and embellished with a wide repertory of decorative motifs, both floral and vegetal, and some belonging to the realm of fantasy (Fig. 8). At the Boim Chapel (16o9-15) in Lviv (Lwów), a complex religious programme was rendered by sculptors using both stone (opokas, siliceous sandstones, limestones and alabasters from the Lviv area), and stuccowork seen both inside and out (Fig. 9 and Fig. 10). ${ }^{58}$ In palaces, stucco was used selectively to articulate the framework of entrances and fenestration, such as for the palace of the Konopnica family in Lublin (1575) which has a rusticated basement and two storeys of windows in grotesque frames, and then an attic topped with an outlandish skyline in order to hide the building's steep roof (Fig. 11 and Fig. 12). A similar approach to palace 


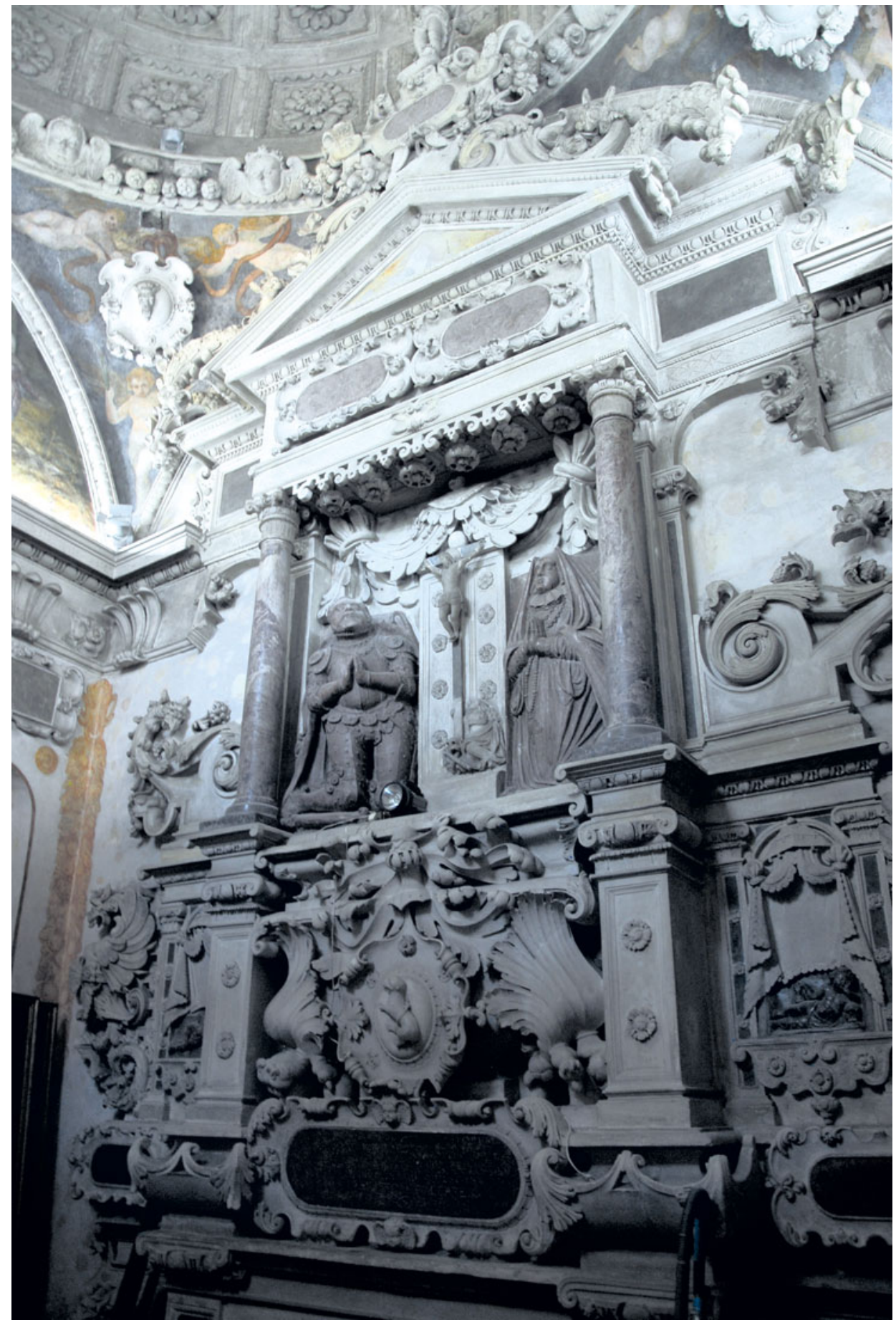

Fig. 8. Bejsce, St Nicolaus Church, Firlej Chapel 


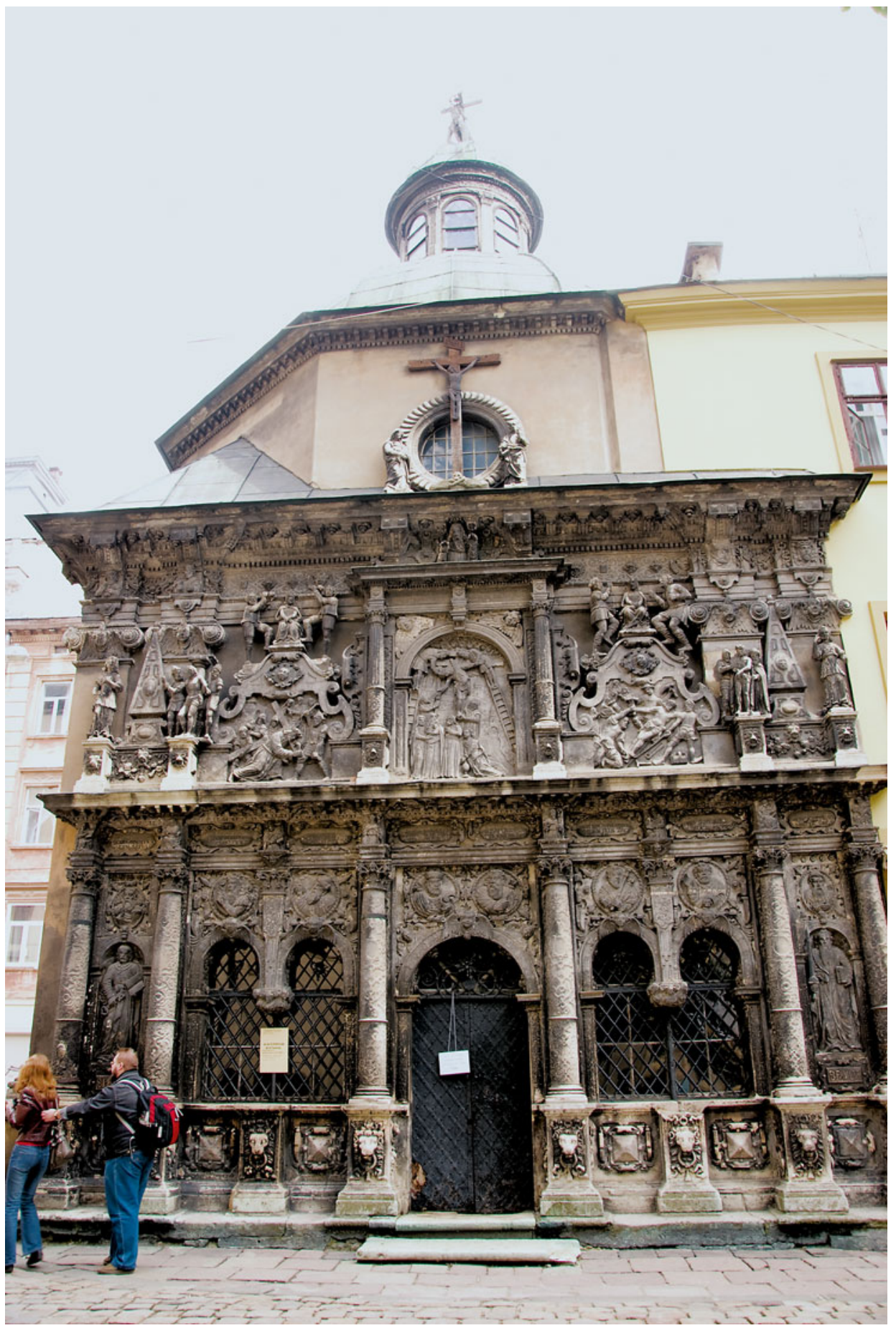

Fig. 9. Lviv, Boim Chapel, exterior 


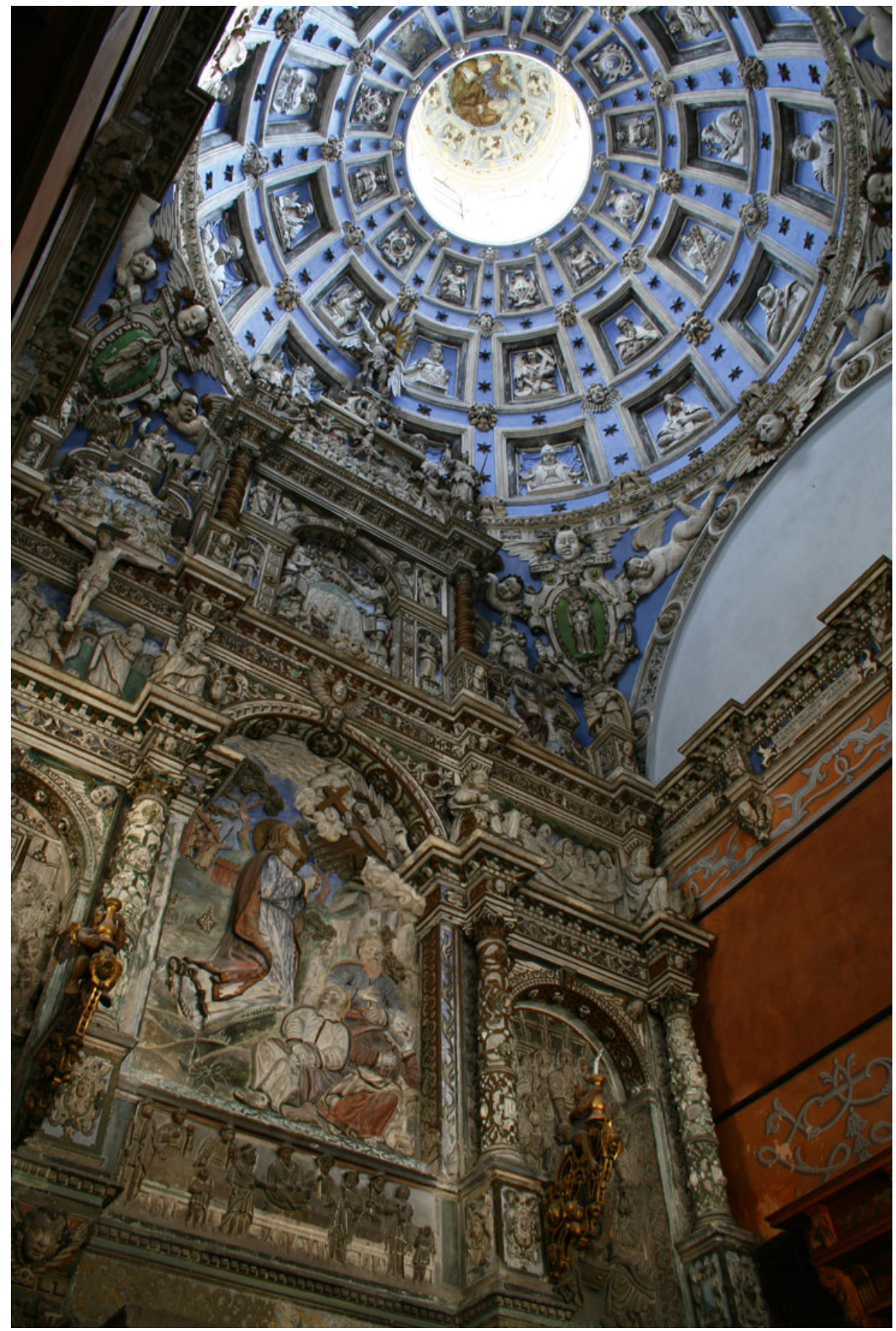

Fig. 10. Lviv, Boim Chapel, interior 
Fig. 11. Lublin, palace once belonging to the Konopnica family, façade

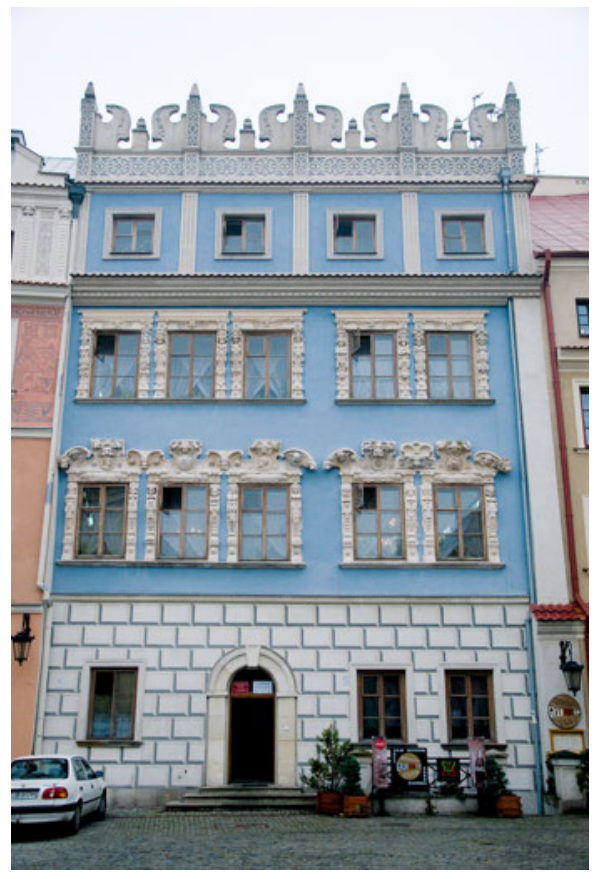

ornamentation can also be seen in the cities of Zamość, Lviv, Kraków and Gdańsk, and this patrician-merchant palace type is especially prevalent in cities that had intense mercantile industries. It is broadly the same type as that later adopted for the Przybyło palaces, and also the Celej palace, (c. 1635) in Kazimierz Dolny, by owners who often travelled to Lublin, Gdańsk and Lviv, and who were thus aware of the mercantile associations now attached to such a format, and of the effectiveness of the format in signalling common purpose and collective success (Fig. 13 and Fig. 14). Many in Kazimierz Dolny would have also been aware that the Przybyło palaces on the Kazimierz Dolny market square and the Celej palace (located on a major thoroughfare) were the most elaborate displays of all-over stucco relief-sculpture in the whole geo-political region of Poland-Lithuania.

\section{THE PALACES OF NICOLAUS AND CHRISTOPHER PRZYBYŁO}

The two adjoining palaces of Nicolaus and Christopher Przybyło on the market square of Kazimierz Dolny are designed to suit their mercantile functions, but with façade decorations that are particularly spectacular. Their frontages are arcaded with stores positioned at street level and domestic quarters situated above. They were not intended, however, to provide living quarters for their owners, who lived in agricultural compounds (folwark) a short walk from the market square, but they were representative of the family's standing, serving as sites of business, ${ }^{59}$ and having their stores and 


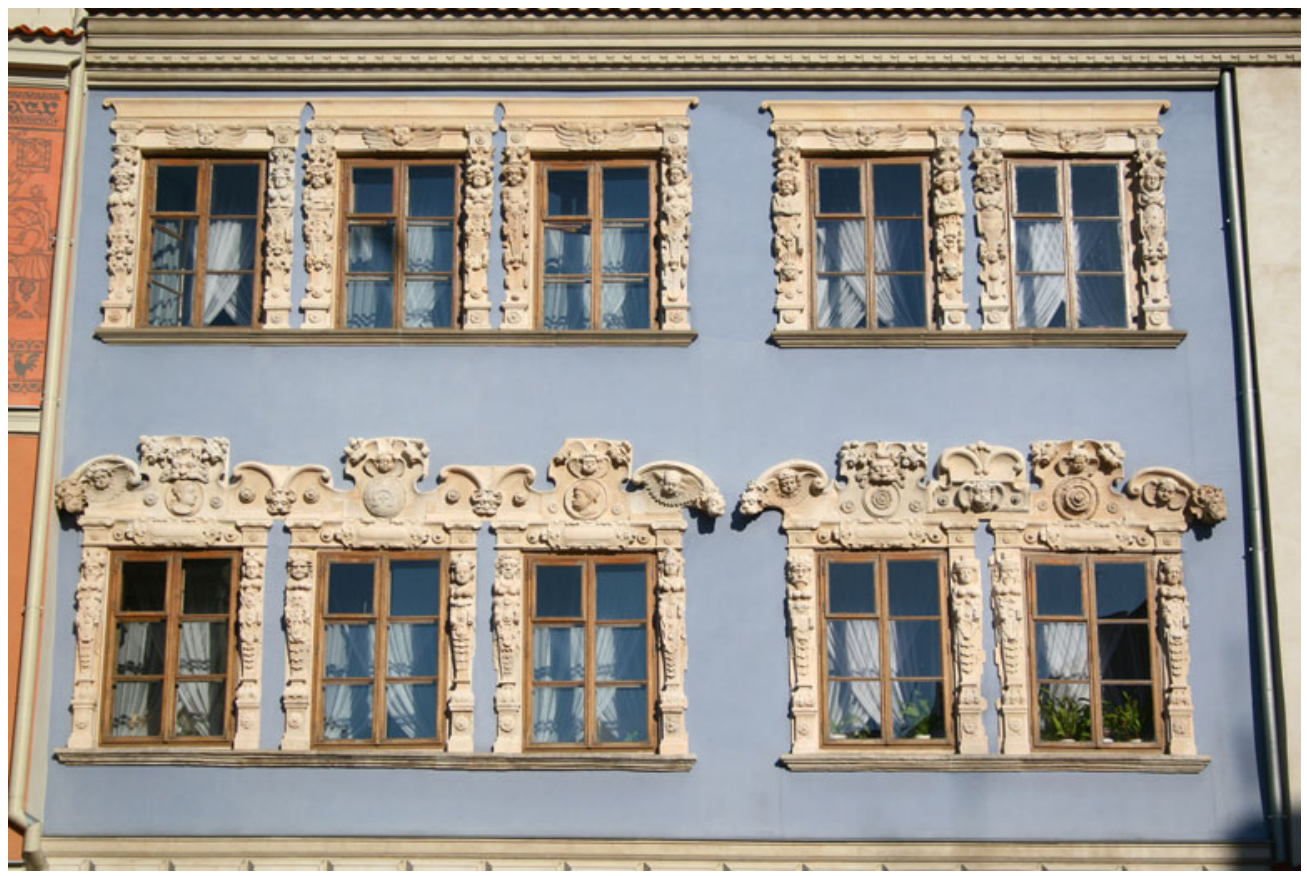

Fig. 12. Lublin, palace once belonging to the Konopnica family, ornamented windows

apartments available to rent. Nevertheless, their exteriors were particularly important, and this importance was enhanced all the more by the joining together of the two Przybyło buildings, which thus amplified their architectural impact. ${ }^{60}$ The family took full advantage of the increased size of the stucco façade, the left-hand portion of which proudly incorporates cartouches containing the initials ' $M$ ' and ' $\mathrm{P}$ ', for Nicolaus (Mikołaj) Przybyło, and the date 'A.D. 1615'. The façades, however, also articulate civic ideals and even preach sermons, through representations of religious subjects such as Christ as the Man of Sorrows, the Virgin Mary, the Evangelists and other saints, Judith holding the head of Holofernes, Salome holding the head of John the Baptist on a platter, which can be all identified by their attributes and inscriptions (Fig. 15), which weave together ideas of civic virtue and piety. ${ }^{61}$ The depiction, for example, of Judith implies bravery and loyalty for the greater good, while the emphatically displayed severed heads (of John the Baptist and Holofernes) signal the corresponding themes of duty and sacrifice. These subjects share space with a relief representing charity as a pelican feeding three young birds, and a cartouche of the Arma Christi alluding to pious devotion and showing a heart with a crown of thorns, hammer and nails. A satyr standing awkwardly pressed against a column on the house of Nicolaus looking towards that of Christopher brings some humour to the otherwise serious iconography (Fig. 16).

The figures and compositions are all incorporated into an architectural framework of all'antica forms which include channelled rustication, herms, pilasters and pediments, 


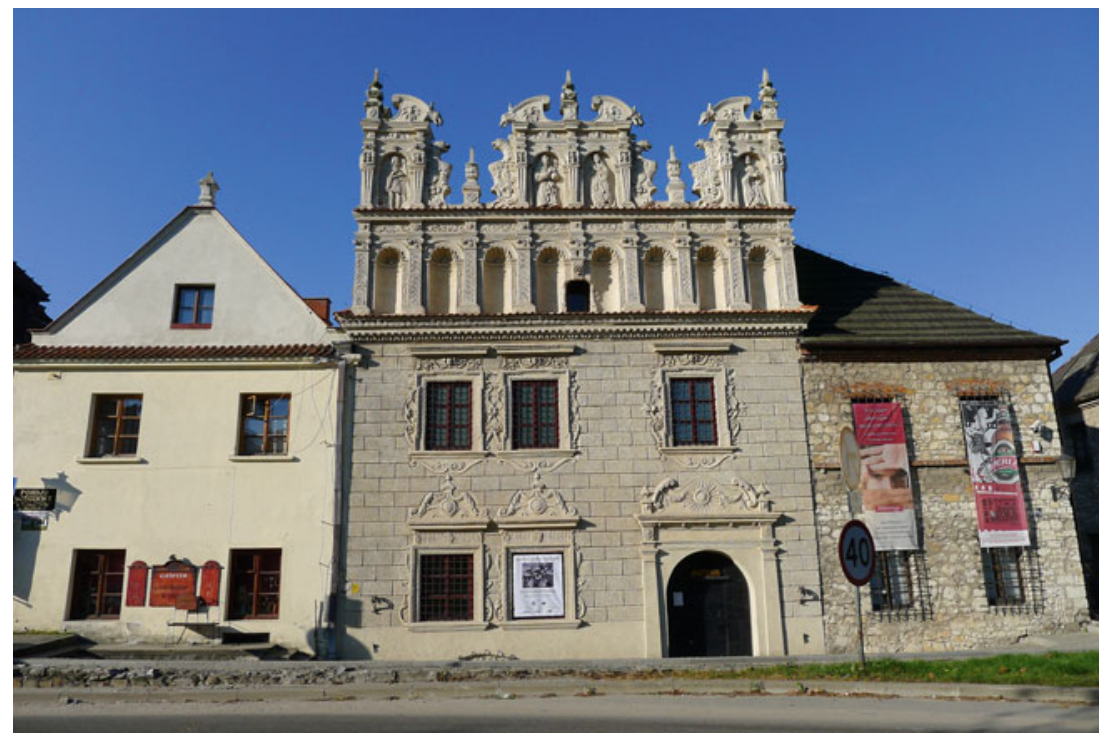

Fig. 13. Kazimierz Dolny, palace once belonging to the Celej family, façade

while shell niches, dolphins, grotesques, festoons and an abundance of strapwork, along with Latin inscriptions that all contribute to the classicising tone of the decoration. The heavy pedimented tabernacles crowning the house of Nicolaus Przybyło, are asymmetrically placed, with the one on the left cut in half. This might seem to be a mistake or a misunderstanding until it is noticed that the tabernacle wraps around the building and the other half is on the side-elevation (Fig. 17). It is perhaps better interpreted, therefore, as a product of a certain design spontaneity - or a kind of architectural sprezzatura, 'a kind of well-bred negligence born of complete self-possession'. ${ }^{62}$ Perhaps more importantly, it makes clear that the building's exterior was not to be visually consumed in one glance but was intended to unfold to a beholder, or to a procession moving through the space of the market square and experienced the architecture whilst in motion. This spatial reading, therefore, emphasises that the palaces were choreographed within a civic and ritualistic context, which was all the more enhanced by the fact that the market square is located between the city's two major religious institutions, the Church of the Annunciation of the Virgin Mary (and Monastery of the Reformers) and the Church of Sts John the Baptist and Bartholomew the Apostle (the parish church) and on a route still used for religions processions from one side of the city to the other.

The façade reliefs with the most emphasis are those showing the name saints of the Przybyło brothers. Saint Nicolaus, the patron saint of sailors and merchants, is depicted on the house of Nicolaus Przybyło while Saint Christopher, the patron saint of merchants and travellers, is shown on that of Christopher Przybyło. ${ }^{63}$ Saint Nicolaus is represented in a rectangular surround and is shown in a frontal pose and as a figure dressed in a long cloak with a bishop's hat and holding a pastoral 


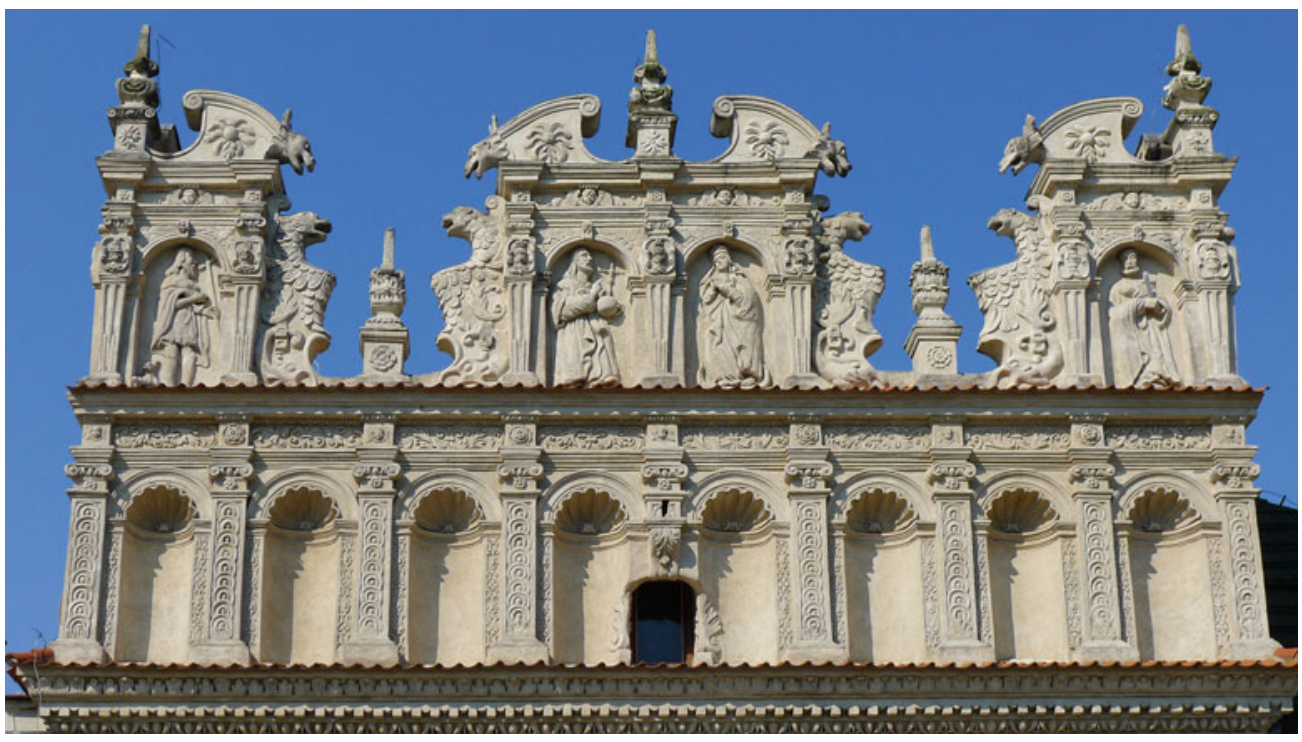

Fig. 14. Kazimierz Dolny, palace once belonging to the Celej family, attic

staff and book, and thus in a manner reminiscent of an icon set within a heavy frame, although enlarged to match the size of the neighbouring windows (Fig. 18). ${ }^{64}$ By being represented in accordance with this iconic tradition, the figure thus references a genre of painting (the icon) and relief sculpture developed originally for the purposes of private devotion. ${ }^{65}$ The figure of Saint Christopher demonstrated a similar idea both literally and metaphorically. Unlike St Nicolaus, St Christopher is not framed but dominates the piano nobile of the next door building, measuring $3.87 \mathrm{~m}$ in height (Fig. 19). ${ }^{66}$ The saint was, as the Golden Legend relates, a 'Christ-bearer', a giant who was also responsible for helping travellers cross a river, ${ }^{67}$ and on the façade he is depicted literally as a giant, with a beard and holding a tree he uses as a staff, while carrying Christ on his shoulder and walking through a pool of water (representing a river) with fish and lobsters swimming around his feet. Saint Christopher represented a multifarious idea of portability because it was understood that he carried Christ four ways: literally on his shoulder across a river, in his body by mortification, in his mind by devotion, and through speech by preaching. ${ }^{68}$ Such an image had widely become a potent symbol of divine intervention in everyday life. ${ }^{69}$ Saint Christopher, being associated with travel, moreover, often found favour in merchant communities and their places of gathering. For travelling merchants and pilgrims an image of the saint had talismanic powers, and, as a Holy Helper, the saint was invoked for protection against the plague and sudden death. ${ }^{70}$ Portraying the saint in the city's most public space would thus have served the wider community, since seeing Christopher's likeness was believed to avert death on that particular day. ${ }^{71}$ The way the saint is represented, moreover, points to its referential nature, and its similarities to images of the saint in other media, these including prints (sometimes 


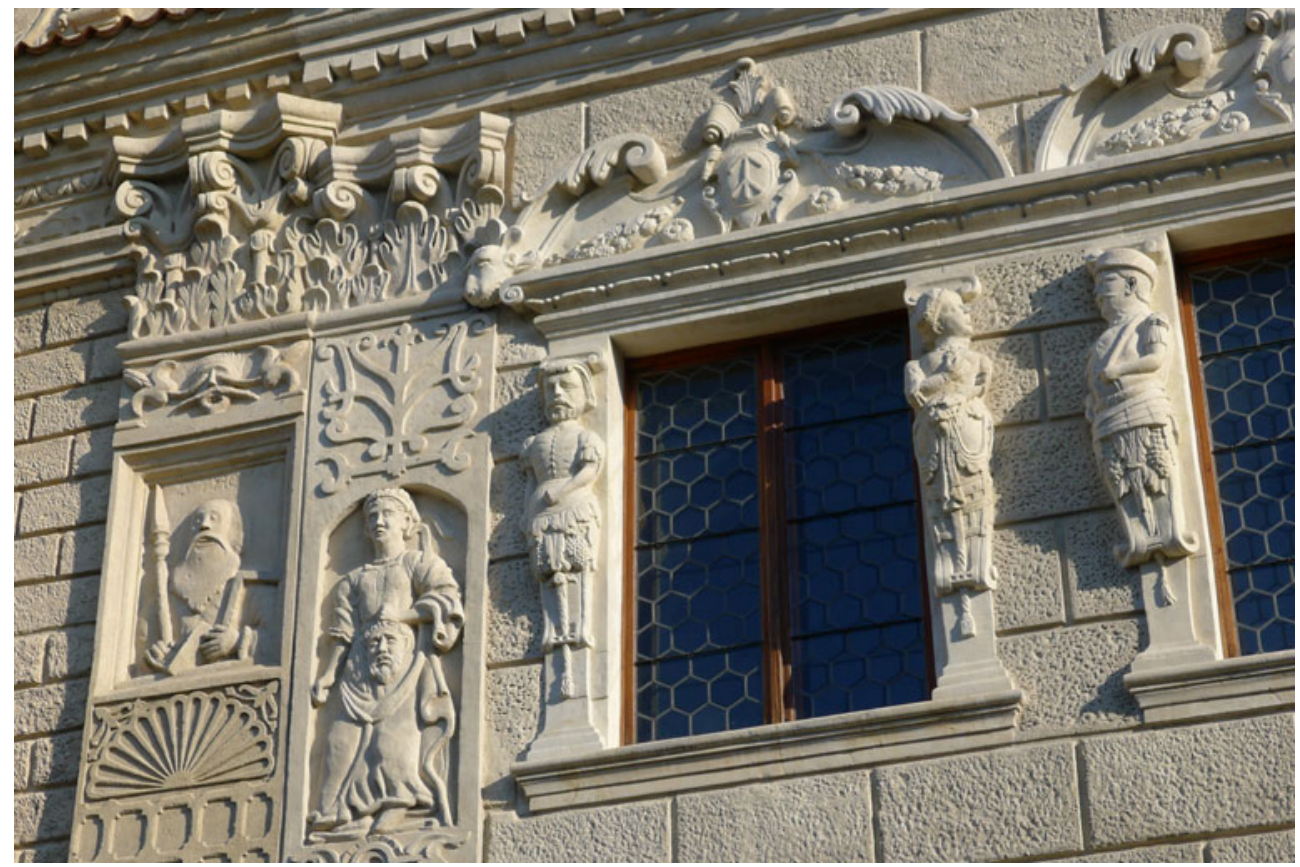

Fig. 15. Kazimierz Dolny, Palaces of Nicolaus and Christopher Przybyło, façades

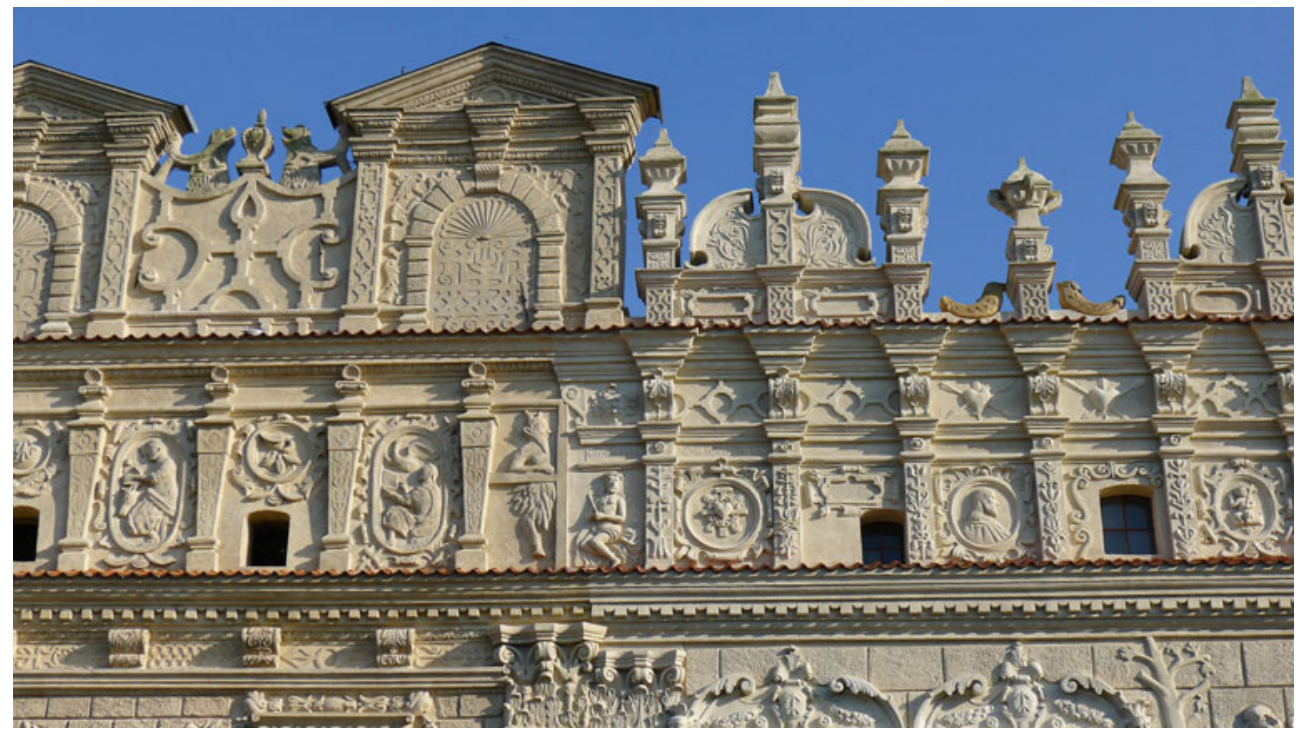

Fig. 16. Kazimierz Dolny, Palaces of Nicolaus and Christopher Przybyło: freeze and attic 


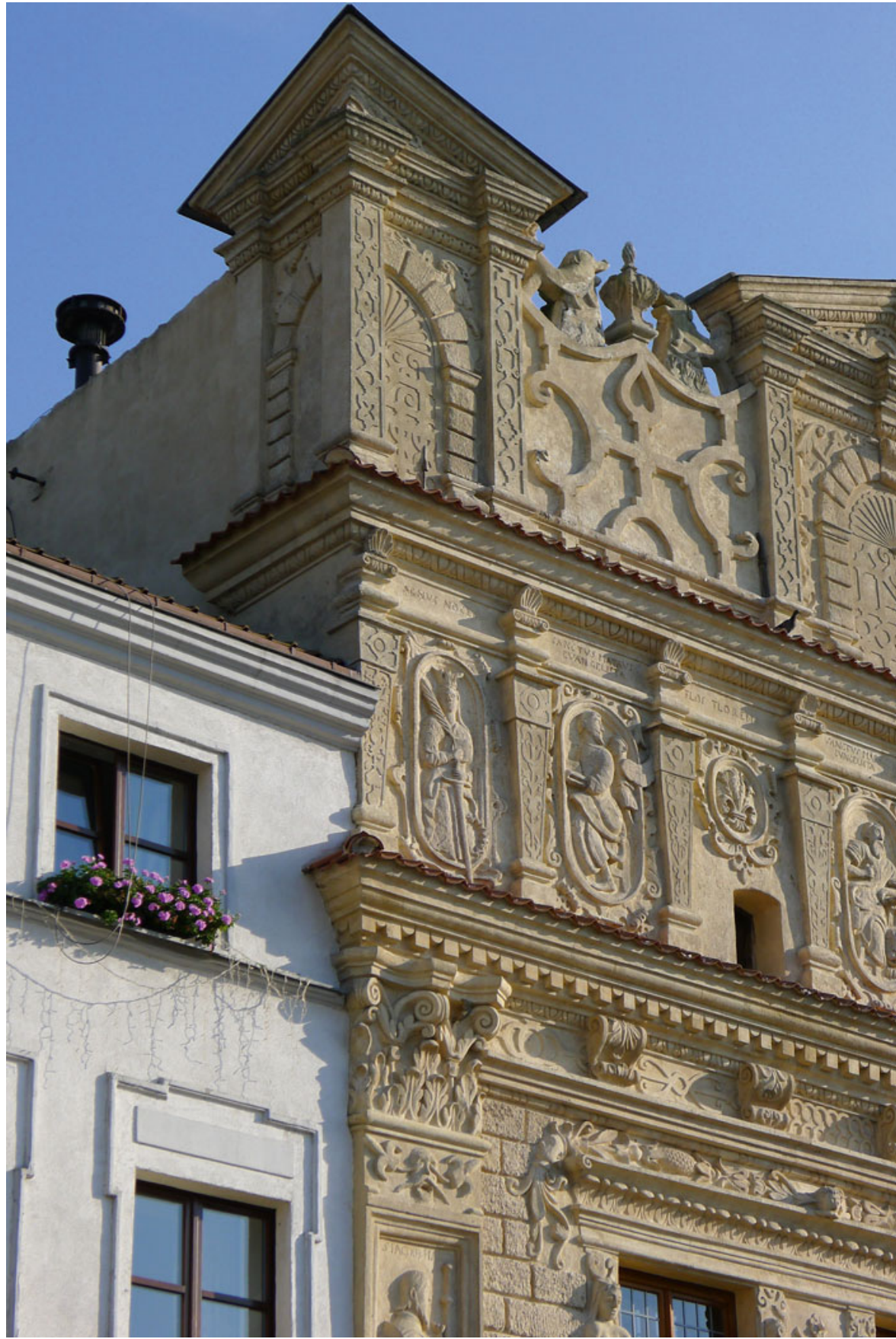

Fig. 17. Kazimierz Dolny, Palace of Nicolaus Przybyło, corner tabernacle 


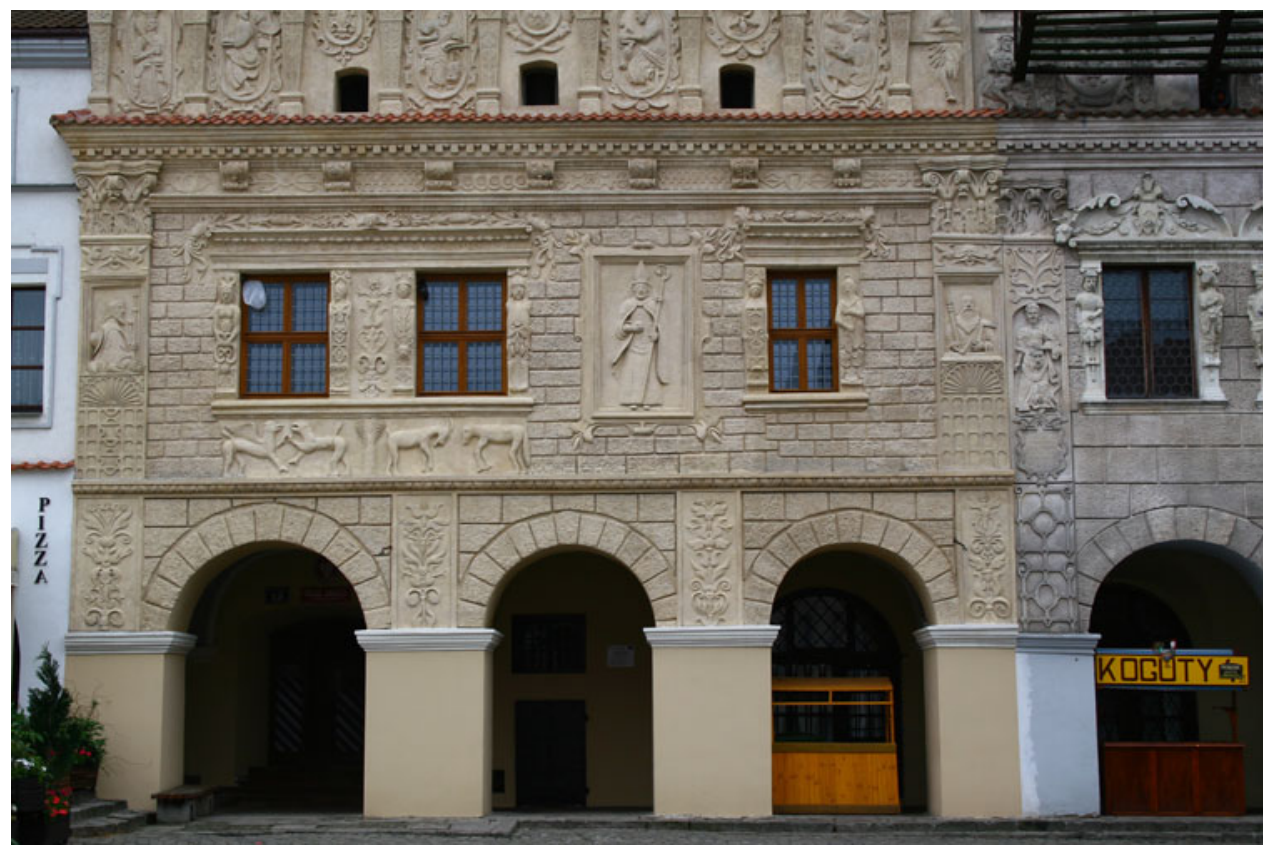

Fig. 18. Kazimierz Dolny, Palace of Nicolaus Przybyło, relief of St Nicolaus

accompanied with statements regarding the image's efficacy), plaquettes intended to be worn, wall paintings in churches, and even meeting halls such as the already mentioned Artus Court in Gdańsk. In all cases, the image had an efficacy that could be carried away and renewed with repeated contact.

The depiction on the façades of the Przybyło palaces of these patron saints provides a useful entry into uncovering the meaning of the relief sculpture there more generally. While there is, as Białostocki noted, no overarching narrative, the reliefs provide a visual compendium intended to evoke and re-transmit familiar devotional ideas and ideals - and in some cases fulfil a vital function of satisfying a daily dose administered through proximity with the iconic type. Each image referenced its own textual source or theological concept, while the architectural surface provided a common site. ${ }^{72}$ The way the image is presented, as we have already noted with those of Saints Nicolaus and Christopher, testifies to the rather different ways it could have been understood, and the associations of other familiar motifs and compositions assembled together on the façades would have been many and various. The images were thus especially potent because they tallied with other images that were familiar through repetition, ${ }^{73}$ such as in prints or small relief designs, and they also testify to the city's strong Catholic religiosity, in the aftermath of the Council of Trent (1563), and to a climate that strongly promoted visual imagery to induce devotion. This religiosity was heightened all the more by the repeated appearance in Kazimierz Dolny of the plague, which accompanied the trading of commodities, but needed to be controlled - it was believed - through 


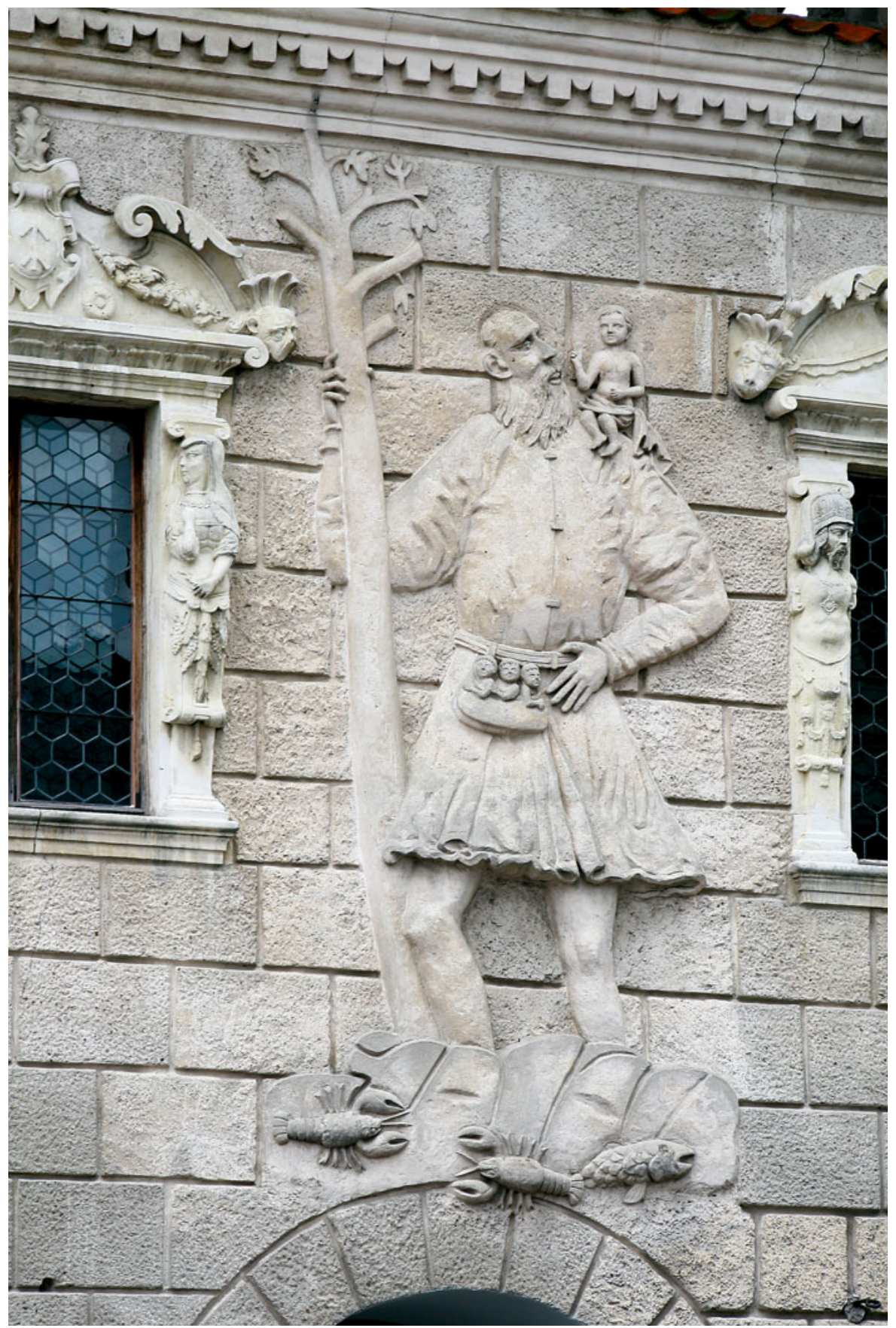

Fig. 19. Kazimierz Dolny, Palace of Christopher Przybyło, relief of St Christopher 
Fig. 20. Poznań Town Hall, façade and left flank

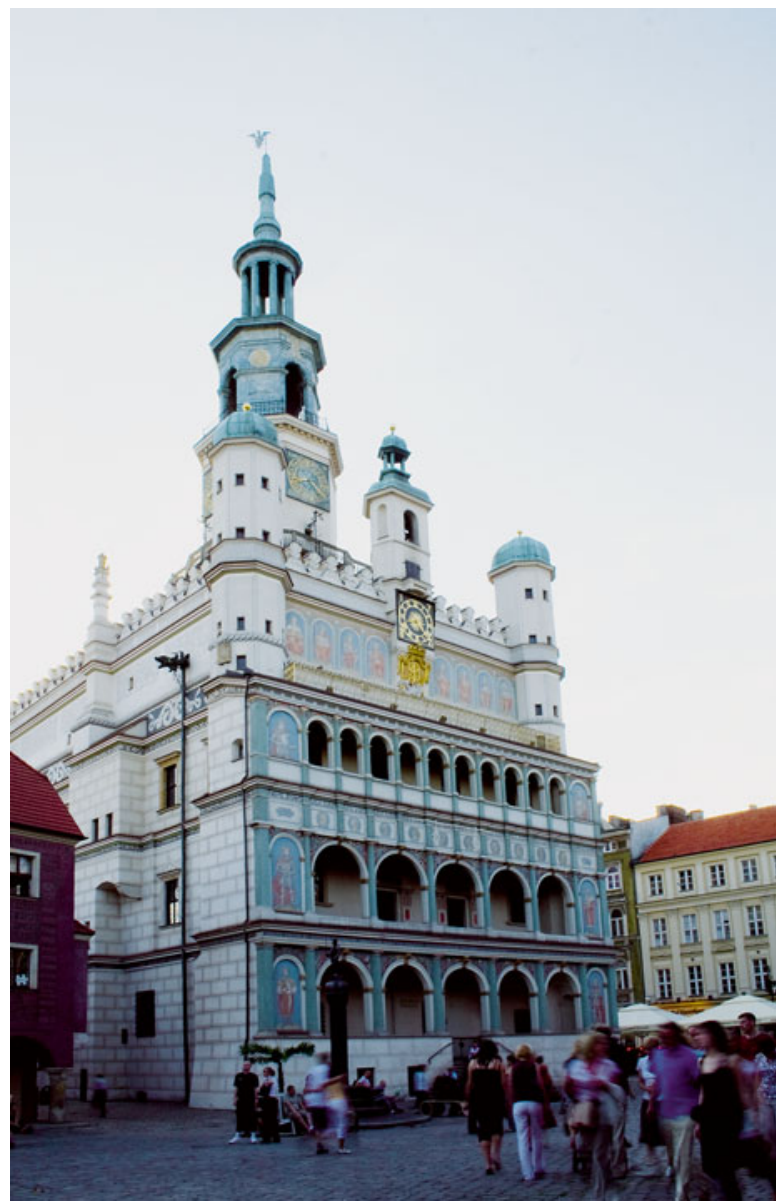

the communal power of prayer and efficacy of images. It also speaks of the Przybyło family securing for the city a point of access to 'portents' ${ }^{74}$ The incorporation of such images on the façades of the Przybyło palaces thus generated a space for communal devotion, which speaks about the potency of affected piety, being charged with messages relating to the community's shared experiences and common civic identity.

In this broader context, the religious imagery included on the façades of the Przybyło palaces is not at all without parallel. Analogous imagery is seen on the exterior of the town hall in Poznań, a city located far from Kazimierz Dolny which therefore forms part of a pattern of references that was indeed traversing the wide region (Fig. 20). Rebuilt by the Italian Giovanni Battista Quadro between 1550 and 1560, the façade served as a frontispicium for the city in that it introduced the civic ideology in the most public manner possible. ${ }^{75}$ The imagery depicted, which was chosen by the patrician ruling class, referenced again Biblical and classical texts, such as civic virtues and female representations of civic loyalty and sacrifice, in this case Lucretia and 


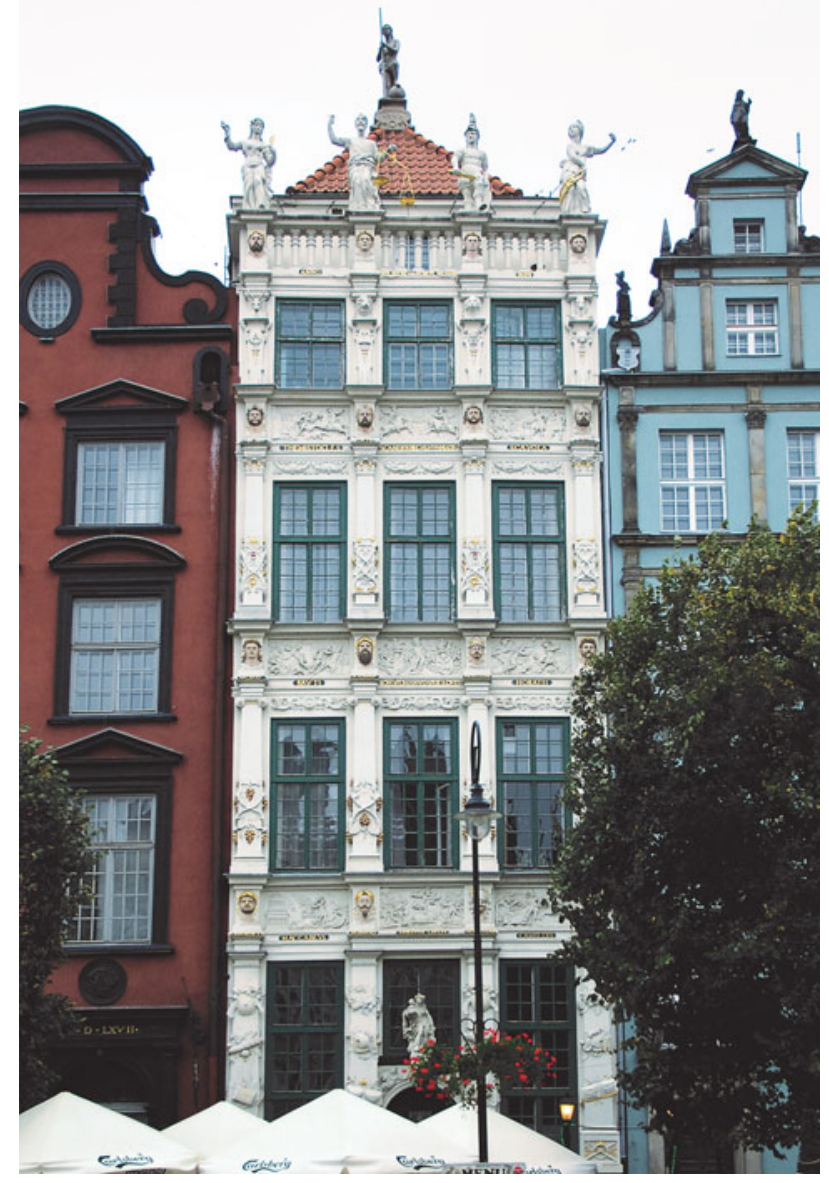

Fig. 21. Gdańsk, Golden House, façade

Cleopatra. Moreover, a rich repertoire was employed of materials and techniques including polychrome, sgraffito, and all'antica architectural elements, ${ }^{76}$ and this likewise encouraged multi-layered iconographic readings alluding to well understood virtues and forging the model for ideal citizen conduct. ${ }^{77}$ Elsewhere, in Gdańsk, the so-called Golden House (1609), belonging to John Speyman, who was to become mayor in 1612, has a façade displaying a range of relief-sculpture depicting allegories, scenes of historical and mythical heroes, and portraits of Polish, European and Roman rulers, together with Speyman's heraldic shield, Latin quotations promoting virtuous civic conduct, three-dimensional sculptures of cardinal virtues (Prudence, Temperance, Fortitude, Justice), and Fortuna at the crown of the building (Fig. 21). ${ }^{78}$ Such comparisons emphasize the civic roles performed by all the buildings. In Kazimierz Dolny, the Przybyłos were not only grain merchants but they were also town councilors with civic duties and religious affiliations. The two palaces on the market square, like their counterparts in other parts of Poland, interacted with the public space of the city, and, 
like them too, they demonstrated their duty to utilise their buildings in their civic endeavors. The façades were not arbitrary in their employment of subjects and techniques of representation, and they were certainly not untutored replicas of Italianate forms, since, instead, they relied on what was now a well-established and widely diffused classical repertory. Through these means, they were vital in shaping a civic ideology that emphasised its conscious participation in a broad cultural arena that relied upon common patterns of values and the transmission of potent and overlapping meanings.

\section{PILGRIMAGE}

Also significant to an understanding of the façade reliefs is that Kazimierz Dolny, in addition to being an important port city, was also a centre of pilgrimage. The destination of this pilgrimage was the Church of the Annunciation of the Virgin Mary and, specifically, a painting of the Annunciation, executed in 1600 by an unnamed local master, and this provides a comparable example of an artwork imbued with spiritual power. The painting, which is based on an engraving of Hendrick Goltzius of 1594, depicts the Virgin Mary as she turns away from an open book towards the angel Gabriel kneeling before her. Being copied from a print, it is another example of the translation of imagery to produce a work of a new impact, because, it was soon believed to perform miracles. ${ }^{79}$ To mark the work's soon- recognised sanctity, it was then accorded with additional embellishments: the Virgin was given a dress as well as gold earrings, armbands, necklaces, rings on her fingers, and a crown encrusted with five amethysts, ten emeralds and three rubies, whilst Gabriel had his wings and the lily he held in his hand gilded, these additional accoutrements thereby validating the image's importance. ${ }^{80}$ Records of the continuing miracles, which even included curing those infected by the plague, were kept and votive offerings were left including metal and wax images of body parts that were healed. This local shrine had a major impact on the city which was slowly forging its built environment to enhance the pilgrims' experience, with a Hill of the Crosses looming over its topography, actual churches, granaries with religious motifs, as well as the merchant palaces that together staged the pilgrimage site and famous river port. This setting stressed the importance of Kazimierz Dolny as a place that offered insurance; for both merchants engaging in mercantile activities, or pilgrims seeking indulgences or miracles. Architecture was fundamental in reference making through repetition and allusion the buildings for trade and religion functioned to propagate the city of Kazimierz well beyond its civic boundaries.

It appears, then, that the re-adaptation and dissemination of religious imagery provided one of the key impulses in the conception of the remarkable façades of the Przybyło palaces, and that these are but one facet of a prevailing culture of imitation. The extent of this imitative culture can be further illustrated by another site in Poland, the so-called House of Loreto (Domek Loretański) in the city of Gołab, built in 163438 next to the Church of Sts Catherine and Florian. This was intended to imitate the Santa Casa at Loreto in central Italy (as encased in marble in 1507) - the building in which the Virgin Mary supposedly received the Annunciation - on the basis of description and measurements taken by the church's pastor, Szymon Grzybowski during a pilgrimage to Italy. The building resembles its Italian prototype to an extent, being 


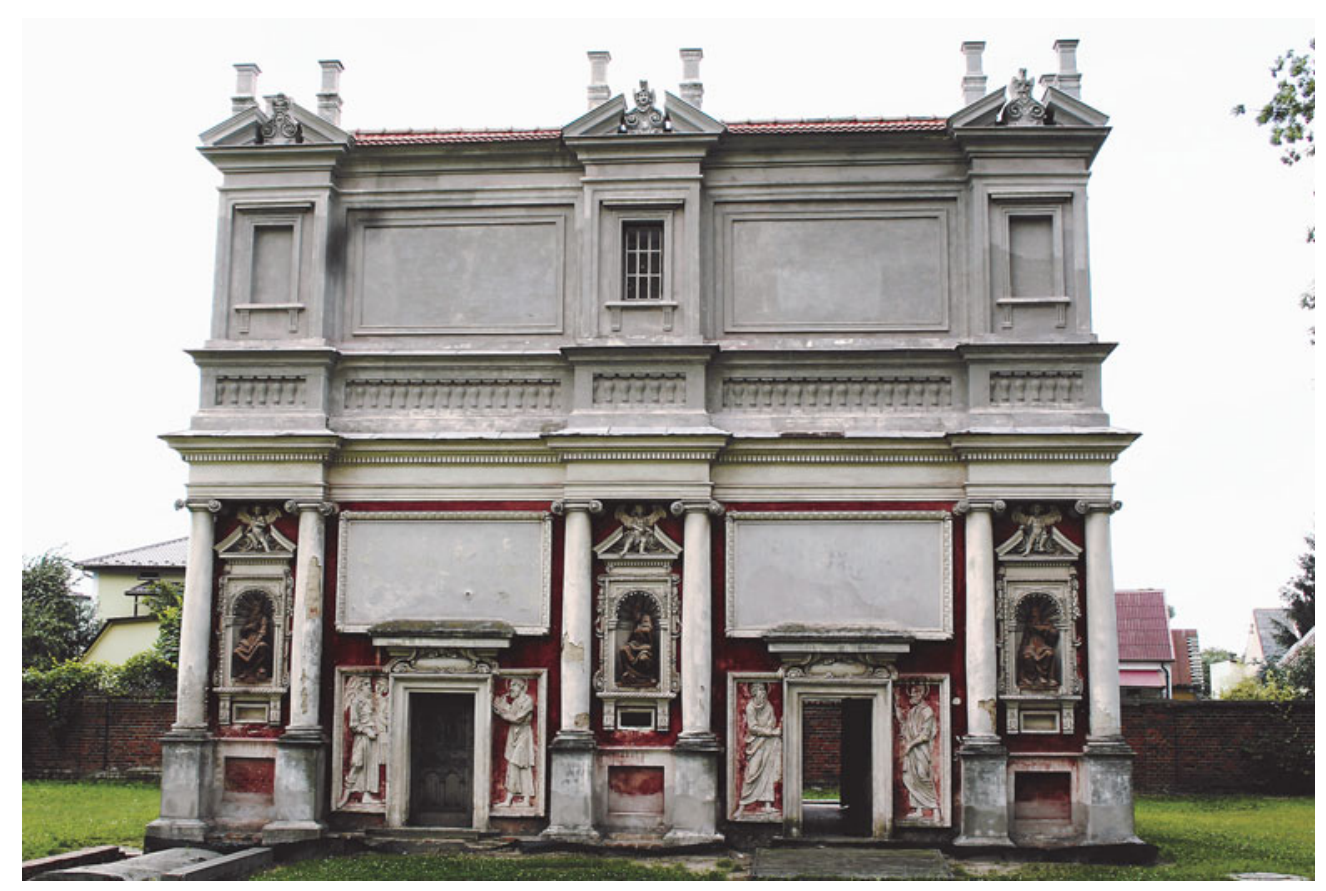

Fig. 22. Golab, House of Loreto, exterior

ornamented with half-columns (albeit Ionic rather than Corinthian), and niches for figures of prophets which flank portals; but now there are two storeys rather than one, and the ornamentation is made from stucco rather than marble (Fig. 22). ${ }^{81}$ The House of Loreto, therefore, treats the idea of resemblance this time in yet another way, as a kind of 'copy' similar to one that has been much explored in the classic article (1942) by Richard Krautheimer and applied in the literature on sacre monti (sacred mountains) and more recently to architecture and pilgrimage. ${ }^{82}$ In these cases, the aim is to reconstruct the prototype largely by replicating dimensions and distances, ${ }^{83}$ so that a work such as the House of Loreto at Gołab, is not a copy per se, in the sense of visual or formal exactitude, but one that enables an identification with the original through meaningful association. ${ }^{84}$ At Kazimierz Dolny, the merchant houses do not reference an architectural original like the House of Loreto, but the manners of their making and understanding were still very much coloured by the same cultural climate. Furthermore, the way in which Kazimierz Dolny utilized reference-making techniques developed in religious settings, sheds light on the architecture of trade and its reliance on similar techniques of participation in a 'self-conscious series' ${ }^{85}$ Within the devotional structure 'copying' was to fulfil the purpose of transferring sanctity of the original to the new, ${ }^{86}$ while in the mercantile context it was to secure an architectural license that articulated the legitimacy through a business ethic. The processes of imitation were, in both commercial and cultic contexts, crucial for creating a site that relied on and competed with a broader cultural network. 
It is commonly held that a regional 'cuisine', in architecture, does not travel, but instead spawns what can be best described a variety of assemblages or collages that are also informed by their own local circumstances. ${ }^{87}$ It is thus difficult, if not impossible, to understand the façades of the Przybyło palaces of Kazimierz Dolny when they are detached from their physical and cultural environments. Emphasising such contexts, especially as they were expressed here through the medium of stucco and low-relief imagery, reveals the complexity of interwoven associations and notions of reference making. The haptic stucco medium that formed the relief sculpture of the Przybyło façades could signal extensive meanings that are layered and engrained into the very fabric of their architectural surfaces, as well as making blanket statements that would overlap onto the city and the wider world beyond.

\section{ACKNOWLEDGEMENTS}

I would like to extend my sincere thanks to David Hemsoll for his comments and advice during the editing stages of this article.

\section{BIOGRAPHY}

Katie Jakobiec studied at the University of Toronto where she gained an MA and PhD in art and architectural history. She is currently the Scott Opler Junior Research Fellow in Architectural History at Worcester College, University of Oxford, where she is working on a book project examining the architecture relating to mercantile exchanges between Poland and the Baltic Sea region during the Early Modern period.

\section{ABSTRACT}

This article builds upon Jan Białostocki's seminal book The Art of the Renaissance in Eastern Europe by examining two merchant palaces in the port city of Kazimierz Dolny on the Vistula River in Poland but departs from his interpretation of them. Focusing on the stucco architecture and relief-sculpture of their façades, the article argues against Białostocki's traditional reading of imitation as being driven by artistic influence, and, through the study of the city's mercantile and pilgrimage context, it proposes instead that a notion of imitation that was deeply immersed in sophisticated practices of copying and reference making. It concludes that the merchant community in Kazimierz Dolny was aiming to forge a new civic identity in order to contend in a broader social, religious and economic realm that was traversed by merchants, travellers and pilgrims alike.

\section{NOTES}

1 Jan Białostocki, The Art of the Renaissance in Eastern Europe. Hungary, Bohemia, Poland (Oxford, 1976). For engagement with Białostocki's work, see Thomas DaCosta Kaufmann, 'Italian Sculptors and Sculpture Outside of Italy (Chiefly in Central Europe): Problems of Approach, Possibilities of Reception', in Reframing the Renaissance: Visual Culture in Europe and Latin America 1450-1650, ed. Claire Farago (New Haven and London, 1995), pp. 47-66; Thomas DaCosta Kaufmann, 'Acculturation, Transculturation, Cultural Difference and Diffusion? Assessing the Assimilation of the Renaissance', in Unity and Discontinuity: Architectural Relationships Between the Southern and Northern Low Countries (1530-1700), ed. Krista De Jonge and Konrad Ottenheym (Turnhout, 2007), pp. 339-49. 
2 Białostocki, The Art of the Renaissance in Eastern Europe, p. 11.

3 Ibid., p. 5 .

4 Ibid. See discussion in Kaufmann, 'Italian Sculptors and Sculpture Outside of Italy', pp. 47- 66.

5 Białostocki, The Art of the Renaissance in Eastern Europe, p. 88.

6 Ibid., pp. 2 and 43.

7 Ibid., p. 88.

8 Donal Cooper and Marika Leino, 'Introduction', in Depth of Field: Relief Sculpture in Renaissance Italy, ed. Donal Cooper and Marika Leino (Bern, 2007), pp. 21 and 29; Bruce Boucher, 'Italian Renaissance Terracotta: Artistic Revival or Technological Innovation', in Earth and Fire: Italian Terracotta Sculpture from Donatello to Canova, ed. Bruce Boucher (New Haven, 2001), p. 31.

9 Białostocki, The Art of the Renaissance in Eastern Europe, p. 88. Białostocki was not the only historian to offer critical assessment of the merchant houses of Kazimierz Dolny; see also Karol Majewski, 'Dekoracja fasad kamienic Przybyłowskich w Kazimierzu', Studia i materiały Lubelskie. Historia Sztuki, 1 (1963), pp. 73-127; Wacław Husarski, Kamienice renesansowe w Kazimierzu Dolnym (Warszawa, 1950); Adam Miłobedzki, 'Ze studiów nad architektura Kazimierza Dolnego', in Granice Sztuki, ed. Jan Białostocki, Ksawery Piwocki et al. (Warszawa, 1972), pp. 95-102; Adam Miłobędzki, Zarys dziejów architektury w Polsce (Warszawa, 1968).

10 Miłobędzki, 'Ze studiów nad architekturą Kazimierza Dolnego', p. 100.

11 Christopher S. Wood, 'Germany's Blind Renaissance', in Infinite Boundaries: Order, Disorder, and Reorder in Early Modern German Culture, ed. Max Reinhart (Kirksville, 1997), pp. 225-244 (pp. 225-26)

12 Kaufmann, 'Italian Sculptors and Sculpture Outside of Italy', p. 57.

13 Carolyn C. Guile, 'Circulations: Early Modern Architecture in the Polish-Lithuanian Borderland', in Circulations in the Global History of Art, ed. Thomas DaCosta Kaufmann, Catherine Dossin, and Béatrice Joyeux-Prunel (Surrey, 2015), pp. 79-96 (p. 80-81).

14 I.A. Richter, ed., The Notebooks of Leonardo da Vinci (Oxford, 1952), p. 330.

15 Cooper and Leino, 'Introduction', in Depth of Field, ed. Cooper and Leino, pp. 21-40 (p. 21). See also Boucher, 'Italian Renaissance Terracotta', pp. 28-29. Boucher discusses the prejudice against terracotta and examines the differences between the subtractive processes in sculpture versus the adding processes.

16 Maria Giulia Barberini, 'Base or Noble Material? Clay Sculpture in Seventeenth-and Eighteenth-Century Italy', in Earth and Fire, ed. Boucher pp. 43-59 (p. 43).

17 Marco Frascari, 'Semiotica Ab Edendo, Taste in Architecture', in Eating Architecture, ed. Jamie Horwitz and Paulette Singley (Cambridge, 2004), pp. 191-203.

18 Białostocki, The Art of the Renaissance in Eastern Europe, pp. 88. In Bialostocki's writing there is further evidence of the paragone debate where he assesses the relief sculpture as a 'striving for concrete forms dominates this decoration: it is plastic, convex, tactile, not painterly but picturesque'. He lists a series of classifying principles, such as painterly versus linear or the Classical sobriety versus Baroque fancifulness as described in Henrich Wölfflin, Principles of Art History: The Problem of the Development of Style in Later Art (ed. New York, 1950; (First published in 1915). See the discussion of these issues in Johnson, 'The Art of Touch in Early Modern Italy', pp. 74-75.

19 Vitruvius, De architectura, 7, Chap. 5; The Ten Books on Architecture, trans. Morris Hicky Morgan (New York, 1960), pp. 210-11.

20 Ibid.; trans. Morgan, p. 211.

21 Ibid.; trans. Morgan, p. 212.

22 Alina Payne, 'Renaissance sgraffito Façades and the Circulation of Objects in the Mediterranean', in Synergies in Visual Culture, ed. Annette Hoffmann and Nicola Suthor (Munich, 2013), pp. 229-41 (p. 229); Alina Payne, 'Wrapped in Fabric: Florentine Façades, Mediterranean Textiles, and A-Tectonic Ornament in the Renaissance', in Histories of Ornament: From Global to Local, ed. Gürlu Necipoğlu and Alina Payne (Princeton, 2016), pp. 274305 (pp. 274-89); Alina Payne, 'Materiality, Crafting and Scale in Renaissance Architecture', Oxford Art Journal (2009), pp. 365-86.

23 Payne, 'Renaissance sgraffito Façades', pp. 231-33; Payne, 'Wrapped in Fabric', pp. 274-89. Studies on Polish sgraffito include: Krystyna Moisan-Jabłońska, 'Sgraffito na fasadzie kamienicy Górskich w Kazimierz Dolnym nad Wisłą i jego pierwowzór graficzny', in Studia nad sztuka renesansu i baroku VIII. Fundator $i$ dzieło w sztuce nowożytnej, cz. III, ed. Jerzy Lileyko and I. Rolska-Boruch (Lublin, 2007), pp. 259-74; Tadeusz Rudkowski, 'Dekoracje sgraffitowe kamienic mieszczańskich w Polsce w XVI i XVII wieku', Kwartalnik Architektury $i$ Urbanistyki, XXX, z. 2 (1985), pp. 227-43; Tadeusz Rudkowski, Polskie sgraffita renesansowe (Warszawa, 2006); Tadeusz Rudkowski, 'Renesansowe sgraffita figuralne na elewacjach kamienic mieszczańskich w Europie 
Środkowej', in Sztuka miast i mieszczaństwa XV-XVIII wieku w Europie Środkowowschodniej, ed. Jan Harasimowicz (Warszawa, 1990), pp. 317-34.

24 Payne, 'Renaissance sgraffito', p. 235. See also The Image in Form: Selected Writings of Adrian Stokes ed. Richard Wollheim (Harmondsworth, 1973), pp. 150-51. Stokes differentiates between the carving and modelling approach in sculptural arts. He states that in the two activities there lies a vast difference that symbolises not only the two aspects of labour, but even the respective roles of male and female. Man, in his male aspect, is the cultivator or carver of woman who, in her female aspect, moulds her products as does the earth'. 25 I discovered the prayer books at the archive of the Parish Church in Kazimierz Dolny. Thanks to John T. McQuillan, assistant curator at the Morgan Library, for explaining the technique to me. See examples of such prayer books in, Ernst Kyriss, Der verzierte europäische Einband vor der Renaissance (Stuttgart, 1957); Mirjam M. Foot, The History of Bookbinding as a Mirror of Society (London, 1998).

26 It has been noted that the depicted rulers are both Catholic and Protestant. This co-existence of faiths will be discussed later in the paper where I argue that it is a theme of architectural iconography to show one's religious identity but to emphasise its tolerant character through juxtaposition of virtues and Latin inscriptions articulating civic ethics and morals.

27 I do not mean metaphorically. It has come to my attention that there were instances of pilgrims bringing back dust and/or scratched building matter collected at holy sites that they mixed into a drink.

28 Katie Jakobiec, 'Architecture of Benefaction: The Last Will and Testament of a Grain Merchant', Journal of Interdisciplinary History, 47: 4 (2017), pp. 1-19.

29 Honorata Obuchowska-Pysiowa, Handel wiślany w pierwszej połowie XVII wieku (Wrocław, 1964), p. 56; Józef Kus, 'Udział Kazimierza Dolnego w spławie wiślanym od XVI do XVIII wieku', in Problemy dziejów i konserwacji miast zabytkowych, ed. R. Szczygieł (Radom, 1990), p. 57; Adam Chruszczewski, 'Kupcy zbożowi i handel zbożem w Kazimierzu Dolnym w drugiej połowie XVI wieku', Roczniki Humanistyczne KUL t. VI, z. 5 (1958), p. 96.

30 Milja Van Tielhof, The 'Mother of all Trades'. The Baltic Grain Trade in Amsterdam From the Late $16^{\text {th }}$ to the Early $19^{\text {th }}$ Century (Leiden, 2002); Artur Attman, The Russian and Polish Markets in International Trade 1500-1650 (Göteborg, 1973), p. 21; Obuchowska-Pysiowa, Handel wiślany, p. 56.

31 Chruszczewski, 'Kupcy zbożowi i handel zbożem', p. 102; Jan M. Małecki, Zwiazki handlowe miast polskich z Gdańskiem w XVI i pierwszej połowie XVII wieku (Wrocław, 1968), p. 121.

32 Adam Miłobẹdzki, 'Architektura i społeczeństwo', in Polska w epoce Odrodzenia: państwo, społeczeństwo, kultura, ed. Andrzej Wyczański (Warszawa, 1986), pp. 357-99 (p. 358). Miłobedzki states that in c.1500 only four per cent of buildings on Crown land were stone (except in Royal Prussia, where there were Teutonic buildings constructed out of brick). See also Adam Miłobẹdzki, 'Architektoniczna tradycja średniowiecza w krajobrazie kulturowym Polski XVI-XVIII w. Sześć propozycji problemowych', in Symbolae historiae artium: studia z historii sztuki Lechowi Kalinowskiemu dedykowane (Warsaw, 1986), pp. 369-70. He writes that stone architecture constituted less than one per cent of urban development, the rest was wood. See also Stanisław Herbst, Miasta $i$ mieszczaństwo renesansu polskiego (Warsaw, 1954), p. 22; Andrzej Wyrobisz, Budownictwo murowane w Małopolsce $w$ XIV i XV wieku. Instytut Historii Kultury Materialnej Polskiej Akademii Nauk: Studia z dziejów rzemiosła i przemysłu, T. 3 (Wrocław, 1963), pp. 36-37 and 40-46. Wyrobisz claims that there was no stone-building tradition in Poland before the introduction of Christianity. Then, stone architecture was limited to the building of churches, fortresses (which were architectural projects funded by the Church or princely patrons), and to a much lesser extent residential buildings; see also Stanisław Żaryń, 'Kamienica warszawska w XV i XVI wieku', Kwartalnik Architektury i Urbanistyki, XXX, z. 2 (1985), pp. 103-25 (p. 106).

33 Archiwum Państwowe w Lublinie (APL), APL-35-37-0, Signature 5, 1614, p. 391; APL-35-37-0, Signature 8, 1632, pp. 417-18.

34 APL-35-37-0, Signature 5, 1613, p. 189; APL-35-37-0, Signature 5, 1613, p. 159; Maria Stankowa, 'Kazimierz nad Wisła i starostwo kazimierskie. Rys historyczny' (unpublished dissertation completed in 1951, Lublin), p. 200; this work is presently held at the Muzeum Nadwiślańskie w Kazimierzu Dolnym (MNK), Archiwum Nr. 3712 DT.

35 Joanna Pinińska, Alicja Bobrawska and Dominik Łukasiak, 'The Influence of Natural Climatic Factors on the Geomechanical Properties of Siliceous Limestones from Kazimierz Dolny (Poland)', Studia Quaternaria, vol. 33, no. 2 (2016), pp. 103-10 (p. 104). See also Beard, Stucco and Decorative Plasterwork in Europe, p. 10. Lime needs to be burned which turns it into 'quick lime', or calcium oxide, and is then 'slaked' with added water to become calcium hydroxide.

36 Jadwiga Teodorowicz-Czerepińska, Rozpoznanie historyczne tzw. Spichlerza Feirsteina w Kazimierzu Dolnym (ul. Puławska 40) (Lublin: 1985), pp. 3-5. This document is at the Muzeum Nadwiślańskie w Kazimierzu 
Dolnym (MNK), Archiwum Nr. 2263 DT. See also Juliusz Dumnicki, Spichrze polskie (Warszawa, 1987), p. 59 (see footnote 99).

37 See for example Georgia Clarke, Roman House-Renaissance Palaces: Inventing Antiquity in Fifteenth-Century Italy (Cambridge, 2003), p. 221. Clarke writes that imitating stone would have been even more important than using 'original' materials because it was a means to display skill. See also Charles Burroughs, The Italian Renaissance Palace Façade: Structures of Authority, Surfaces of Sense (Cambridge, 2002), p. 64.

38 Adam Miłobedzki, 'Architecture in Wood: Technology, Symbolic Content, Art', Artibus et Historiae, vol. 10, no. 19 (1989), pp. 177-206 (p. 177).

39 Translating the term kamienica into English is a challenge. According to the Pocket Oxford - PWN Polish Dictionary (Oxford, 2005), p. 121, a kamienica is a 'tenement house'. Scholars have also used the term 'burgher house' (Bürgerhaus in German), or alternatively 'town house' or 'patrician house'. The term 'tenement' would suggest that this type of building was always tenanted or, in other words, divided into separate areas or apartments and used by various tenants and renters; but, although the conversion of the single-family house into a tenement did occur sporadically in other cities in Poland as early as the end of the sixteenth century, this cannot be said for every kamienica and it certainly does not present the range of its uses over time. See J.A. Simpson and E.S.C. Weiner, 'Tenement,' The Oxford English Dictionary, Second Edition, vol. XVII (Oxford, 1989), pp. 774-75. See also Ewa Krẹlewska-Foksowicz, 'Kamienica miejska w Polsce do końca XVIII wieku', Kwartalnik Architektury i Urbanistyki, XXX, z. 2 (1985), pp. 99-103 (p. 105); Jan Tajchman, 'Przemiany funkcjonalne toruńskiego domu mieszczańskiego w czasach nowożytnych', Kwartalnik Architektury $i$ Urbanistyki, XXX, z. 2 (1985), pp. 111-33 (p. 133).

40 Ibid.

41 In the archives, there are multiple references to patrons supplying materials. In one case a patron failed to abide by the contract and delayed the workmen who brought the case to court; APL-35-37-0, Signature 5 , p. 399; APL-35-37-0, Signature 6, pp. 181-82.

42 Claire Gapper and Jeff Orton, 'Plaster, Stucco and Stuccoes', Journal of Architectural Conservation, 17:3 (2011), pp. 7-22; Roger Ling, 'Stuccowork', Stuccowork and Painting in Roman Italy, ed. Roger Ling (Aldershot, 1999), pp. 209-21 (p. 209).

43 Michael Clarke, 'Stucco', The Concise Oxford Dictionary of Art Terms, Second Edition (Oxford, 2010), no page number.

44 Vitruvius, De architectura, 7, Chaps 2-6; trans. Morgan, p. 207.

45 Ibid.; trans. Morgan, pp. 204-14.

46 Pliny, Historia naturalis, 36, 53, 174; Natural History in Ten Volumes X: Libri XXXVI-XXXVII, trans. D. E. Eichholz (Cambridge, 1962), p. 137.

47 Ibid., 36, 53, 174- 55, 177; trans. Eichholz, pp. 137-41.

48 Leon Battista Alberti, On the Art of Building in Ten Books, trans. Joseph Rykwert, Neil Leach and Robert Tavernor (London, 1988), Book 2, Chapter 11, pp. 53-56.

49 Gapper and Orton, 'Plaster, Stucco and Stuccoes', p. 10.

50 Ling, 'Stuccowork', p. 215. See also Geoffrey Beard, Stucco and Decorative Plasterwork in Europe (London, 1983), pp. 9-11. Beard writes that chopped animal hair was added to stucco to create the armature.

51 The Image in Form: Selected Writings of Adrian Stokes, ed. Wollheim, p. 156. See also Monika Schmitter, 'Falling Through the Cracks: the Fate of Painted Palace Façades in Sixteenth-Century Italy', in The Built Surface: Architecture and the Pictorial Arts from Antiquity to the Enlightenment, ed. Christy Anderson (Aldershot, 2002), pp. 130-61 (p. 153).

52 Gapper and Orton, 'Plaster, Stucco and Stuccoes', p. 9; Giorgio Vasari, Vasari on Technique, ed. G. Baldwin Brown (New York, 1960), pp. 170-72.

53 Giorgio Vasari, Le vite de' più eccellenti pittori, scultori ed architetti, ed. Gaetano. Milanesi, 9 vols (Florence 1878-85), 6, pp. 551-57.

54 Gapper and Orton, 'Plaster, Stucco and Stuccoes', pp. 10-11.

55 Vasari, Le vite, 4, p. 160.

56 Kaufmann, 'Italian Sculptors and Sculpture Outside of Italy', pp. 62-63.

57 Miłobędzki, 'Ze studiów nad architektura Kazimierza Dolnego', p. 1oo.

58 Marek Rembiś, A. Smoleńska, 'Kamień w architekturze i rzeźbie Kaplicy Boimów we Lwowie', Kwartalnik Architektury i Urbanistyki, t. LI, z. 1-4 (2007), pp. 147-159.

59 Here I am discussing the Przybyło houses and not making a general claim about the other kamienice in Kazimierz Dolny. The archives speak about the different uses of the houses at different times; they were rented for their apartments and stores. Nicolaus Przybyło uses the main chamber of his kamienica to draft 
his last will and testament in the presence of male witnesses, which shows that the house could have been regularly used as a meeting space for formal and business transactions (APL-35-37-0, Signature 5, 1614, pp. 423-24; APL-35-37-O, Signature 5, 1615, p. 427).

60 I discuss the significance of this in Jakobiec, 'Architecture of Benefaction', pp. 1-19.

61 Husarski, Kamienice renesansowe w Kazimierzu Dolnym, p. 26; Majewski, 'Dekoracja fasad kamienic Przybyłowskich w Kazimierzu', p. 89.

62 John Shearman, Mannerism (London, 1967), p. 21.

63 Czekierski, 'Kazimierz Dolny', p. 34.

64 For a discussion of frames see Peter Dent, 'Contemplative Relief: Meditating on Christ through Sculptural Form in Early Trecento Italy', in Depth of Field, ed. Cooper and Leino), pp. 41-69 (p. 42). Dent talks about the use of frames with the aim to imitate the painted panel, or the 'chiselled picture' or 'sculpted image'.

65 Geraldine A. Johnson, 'Art or artefact? Madonna and Child Reliefs in the Early Renaissance', in The Sculptural Object 1400-1700, ed. Stuart Currie and Peta Motture (Brookfield, 1997), pp. 1-17 (p. 3); Gert Kreytenberg, 'Ein doppelseitiges Triptychon in Marmor von Tino di Camaino aus der Zeit um 1334', in Medien der Macht. Kunst zur Zeit der Anjous in Italien, ed. Tanja Michalsky (Berlin, 2001), pp. 262-74; Johnson, 'The Art of Touch in Early Modern Italy', pp. 59-84; Max Seidel, Italian Art of the Middle Ages and the Renaissance (Venice, 2005); Dent, 'Contemplative Relief', pp. 41-69.

66 Krystyna Trzeciak et al., Kazimierz Dolny. Konserwacja kamienic Przybyłowskich 1982-1987 r. Maszynopis (MNK), Archiwum Nr. 3389 DT, pp. 1-12.

67 David Farmer, Oxford Dictionary of Saints (Oxford, 1997), pp. 100-01.

68 Jacobus Voragine, The Golden Legend, trans. G. Ryan and H. Ripperger (London, 1941), p. 377.

69 Edward Muir, 'The Virgin on the Street Corner: The Place of the Sacred in Italian Cities', in Religion and Culture in the Renaissance and Reformation, ed. Steven Ozment (Kirksville, Mo, 1989), pp. 25-40 (pp. 25-26); Peta Motture, 'Making and Viewing: Donatello and the Treatment of Relief', in Depth of Field: The Place of Relief in the Time of Donatello, ed. Penelope Curtis (Leeds, 2005), pp. 18-29 (p. 19). Sell also John T. Paoletti, 'Familiar Objects: Sculptural Types in the Collections of the Early Medici', in Looking at Italian Renaissance Sculpture, ed. Sarah Blake McHam (Cambridge, 1998), pp. 79-110 (p. 81); Dent, 'Contemplative Relief', p. 67. 70 J. Dünninger, 'Fourteen Holy Helpers', in New Catholic Encyclopaedia, vol. 5, $2^{\text {nd }}$ ed. (Detroit, 2003), pp. 83637; Farmer, Oxford Dictionary of Saints, 100-01; John Henderson, The Renaissance Hospital: Healing the Body and Healing the Soul (New Haven and London, 2006), p. 126.

71 Farmer, Oxford Dictionary of Saints, pp. 100-01. See also the example given by Wood of an indulgence woodcut showing a wound of Christ in actual size that Pope Innocent promised insurance against death for those who kissed the printed cross, Wood, 'Germany's Blind Renaissance', p. 240.

72 Christy Anderson, Inigo Jones and the Classical Tradition (Cambridge, 2007), p. 108. See also Burroughs, The Italian Renaissance Palace Façade, p. 28; Michael Bath, Speaking Pictures: English Emblem Books and Renaissance Culture (London, 1994), pp. 31-32. As Charles Burroughs stated about the Renaissance façade, 'meaning arises in a process of interpretation that is open-ended and even ludic, responsive to allusions and cues that invite further reflection, rather than enforcing a single, universally binding construal'.

73 Paoletti, 'Familiar Objects', p. 81.

74 Peter Parshall, 'Imago Contrafacta: Images and facts in the Northern Renaissance', Art History, v. 16, issue 4 (1993), pp. 554-579 (p. 565).

75 Lucyna Sieciechowiczowa, Życie codzienne w renesansowym Poznaniu 1518-1619 (Warszawa, 1974), pp. 17-18. Jerzy Kowalczyk, 'Fasada ratusza poznańskiego. Recepcja form z traktatu Serlia i artystyczny program', Rocznik Historii Sztuki, t. VIII (1970), pp. 141-173.

76 Kowalczyk, 'Fasada ratusza poznańskiego', pp. 141-173.

77 Kowalczyk, 'Fasada ratusza poznańskiego', pp. 164-165.

78 Jacek Bielak, ‘Ikonografia Złotej Kamienicy na nowo odczytana. O związkach polityki, kultury i sztuki w Gdańsku początku XVII wieku,' in Mieszczaństwo gdańskie, ed. Stanisław Salmonowicz (Gdańsk, 1997), pp. 377-392.

79 Archivum Conventus Casimiriensis P.P. Reformatorum ad Aedes B.V. Mariae ab Archangelo Salutatae, p. 16. The painting is oil on panel $(210 \times 119 \mathrm{~cm})$. The manuscript is located at the Archiwum Prowincji FranciszkanówReformatów w Krakowie (APFR).

8o Ibid. p. 113, 120. For a discussion of cultic imagery see, Caroline Walker Bynum, Christian Materiality: An Essay on Religion in Late Medieval Europe (New York, 2011), pp. 53-59.

81 Stanisław Michalczuk, 'Domek loretański w Gołębiu. Geneza jego treści ideowych i artystycznych', in Treści dzieła sztuki (Warszawa, 1969), pp. 153-71. 
82 Richard Krautheimer, 'Introduction to an "Iconography of Medieval Architecture"', Journal of the Warburg and Courtauld Institutes, v. 5 (1942), pp. 1-33. See also Paul Davies, Deborah Howard and Wendy Pullan, eds., Architecture and Pilgrimage 1000-1500: Southern Europe and Beyond (Farnham, 2013).

83 Alessandro Nova, "Popular" Art in Renaissance Italy: Early Response to the Holy Mountain at Varallo', in Reframing the Renaissance: Visual Culture in European and Latin America 1450-1650, ed. Claire Farago (New Haven and London, 1995), pp. 113-26; William Hood, 'The Sacro Monte of Varallo: Renaissance Art and Popular Religion', in Monasticism and the Arts, ed. Timothy Verdon (New York, 1990), pp. $291-311$.

84 See this idea in Krautheimer 'Introduction to an 'Iconography of Medieval Architecture', pp. 1-33.

85 See these ideas in Robert Maniura, 'Two Marian Image Shrines in Fifteenth-Century Tuscany, the 'Iconography of Architecture' and the Limits of 'Holy Competition', in Architecture and Pilgrimage 10oo1500: Southern Europe and Beyond, eds. Paul Davies, Deborah Howard and Wendy Pullan (Farnham, 2013), pp. 213-229 (p. 220-21); Paul Davies, 'Likeness in Italian Renaissance Pilgrimage Architecture', in Architecture and Pilgrimage 1000-1500: Southern Europe and Beyond, eds. Paul Davies, Deborah Howard and Wendy Pullan (Farnham, 2013), pp. 187-211; Paul Davies, 'The Madonna delle Carceri in Prato and Italian Renaissance pilgrimage architecture', Architectural History, 36 (1993), pp. 1-18.

86 Davies, 'Likeness in Italian Renaissance Pilgrimage Architecture', p. 197.

87 Paulette Singley and Jamie Horwitz, 'Introduction', in Eating Architecture, pp. 5-17; Allen S. Weiss, 'Culinary Manifestations of the Genius Loci', in Eating Architecture, pp. 21-32. 